\title{
Shareholder Diversification, Bank Risk-Taking and Capital Allocation Efficiency
}

Link to publication record in Manchester Research Explorer

\section{Citation for published version (APA):}

García-Kuhnert, Y., Marchica, M-T., \& Mura, R. (2015). Shareholder Diversification, Bank Risk-Taking and Capital Allocation Efficiency.

\section{Citing this paper}

Please note that where the full-text provided on Manchester Research Explorer is the Author Accepted Manuscript or Proof version this may differ from the final Published version. If citing, it is advised that you check and use the publisher's definitive version.

\section{General rights}

Copyright and moral rights for the publications made accessible in the Research Explorer are retained by the authors and/or other copyright owners and it is a condition of accessing publications that users recognise and abide by the legal requirements associated with these rights.

\section{Takedown policy}

If you believe that this document breaches copyright please refer to the University of Manchester's Takedown Procedures [http://man.ac.uk/04Y6Bo] or contact uml.scholarlycommunications@manchester.ac.uk providing relevant details, so we can investigate your claim.

\section{OPEN ACCESS}




\title{
Shareholder Diversification, Bank Risk-Taking and Capital Allocation Efficiency
}

\author{
Yamileh García-Kuhnert \\ Manchester Business School \\ Accounting and Finance Division \\ Booth Street East \\ Manchester M13 9PL \\ e-mail: yamileh.garciabelen@postgrad.mbs.ac.uk \\ Maria-Teresa Marchica^ \\ Manchester Business School \\ Accounting and Finance Division \\ Booth Street East \\ Manchester M13 9PL \\ e-mail:maria.marchica@mbs.ac.uk \\ phone: $+44(0) 1612750121$ \\ Roberto Mura \\ Manchester Business School \\ Accounting and Finance Division \\ Booth Street East \\ Manchester M13 9PL \\ e-mail: roberto.mura@mbs.ac.uk
}

Acknowledgments: We thank Bernard Black, Mara Faccio, Marc Goergen, Christiane Kneer, Luc Renneboog, seminar participants at Manchester Business School, Northwestern University "2012 Causal Inference Workshop", at the Central Bank of Dominican Republic, at the Cambridge-CGIR conference, Cardiff Business School "Corporate Governance and Investment Workshop", and at FIRS 2013 for helpful comments. Special thanks to Bobby Foster from Bureau van Dijk and Zhonglun Nie for his excellent research assistance. The usual disclaimers apply.

` Corresponding author 


\title{
Shareholder Diversification, Bank Risk-Taking and Capital Allocation Efficiency
}

\begin{abstract}
Using the entire universe of Bankscope and Amadeus Top 250,000 we construct the portfolios of shareholders who hold equity stakes in publicly traded and privately held European banks for each year over the period 1999-2008. We show that about $62 \%$ of banks' ultimate largest shareholders are diversified investors, holding on average equity investments from thirteen companies in their portfolio. We exploit this heterogeneity to investigate: 1) the impact of their portfolio diversification on bank risktaking; and 2) the implications of portfolio diversification on the efficiency of capital allocation. Our results show that the relation between portfolio diversification and bank risk-taking is both statistically significant and economically sizeable. We further show that portfolio diversification has a positive and significant effect on the efficiency of capital allocation. Overall, these findings contribute to the literature by studying for the first time a specific channel through which financial development, in the form of bank shareholders' diversification, affects both the banks' risk-taking decisions and the real economy.
\end{abstract}

Key words: Largest shareholder portfolio diversification; bank risk-taking; capital allocation efficiency

JEL Classification: G11, G15, G21, G32, O16 


\section{Introduction}

The pivotal role of financial intermediaries in general, and banks in particular, is to choose which firms get to use society's savings (Schumpeter, 1934). This allows the economic system to grow and decreases aggregate volatility by redistributing risks (e.g., Levine, 1997 and 2005, for extensive surveys). The recent financial crisis has highlighted the degree to which global economies are exposed to (excessive) risk-taking by banks. ${ }^{1}$ Yet little is known about the drivers behind risk-taking behaviour by banks.

In this paper we study a specific determinant of risk-taking, the portfolio diversification of banks' largest shareholders. We provide evidence that banks whose largest shareholders are more diversified take more risks than those whose largest shareholders have relatively less diversified portfolios. We further show that portfolio diversification has a positive and significant effect on capital allocation.

Controlling shareholders who are more diversified have generally stronger incentives to undertake riskier projects. They are less concerned with the firm specific risk than shareholders who have most of their wealth concentrated in one single firm (Jensen and Meckling, 1976). Parrino et al. (2005) show in their simulations how diversified wealth makes agents less risk averse in taking investment decisions; while Faccio, et al., (2011) provide strong empirical evidence of a positive relation between large shareholder portfolio diversification and risk-taking in non-financial companies.

Previous studies in the banking literature have used ownership as a proxy for wealth diversification and often find contrasting results. Saunders et al. (1990) find that (small) increases in managerial stock ownership make managers more closely aligned with shareholder incentives to undertake more risk. Anderson and Fraser (2000) show a negative relation between managerial ownership and bank risk-taking only when regulations designed to reduce risk-taking are in place. Knopf and Teall (1996) document an inverse relation between thrift institutions risk-taking and the level of ownership by institutional investors which are assumed to be diversified shareholders. Laeven and Levine (2009), on the contrary, find that bank risk-taking is higher when banks are owned by powerful shareholders with large cash flow rights.

To our knowledge Sullivan and Spong (2007) is the only work that studies the effect of insiders' personal wealth on risk-taking decisions; their study covers a small sample of US banks between 1993 and 1994. They find that bank earnings volatility decreases when insiders' wealth is more concentrated in the bank they manage.

Using the entire universe of Bankscope and Amadeus Top 250,000 we are able to construct the portfolio of the ultimate largest shareholders of publicly traded and privately held European banks for each year over the period 1999-2008. The European banking system is one of the largest among those in

\footnotetext{
1"The depth and severity of the crisis were amplified by weaknesses in the banking sector such as excessive leverage, inadequate and low quality capital, and insufficient liquidity buffers [...] Moreover, failure to capture major on and offbalance sheet risks, as well as derivative related exposures, was a key factor that amplified the crisis [...]" (Basel Committee, 2010a, p.4).
} 
the developed economies. In its latest report, the European Banking Federation shows that at the end of 2010 European banks held on average five and six times more assets than the US and Japanese banks respectively. Further, the percentage of bank deposits on total GDP in Europe was reported as 139\%, while the same figure was around 59\% in the US and 137\% in Japan. Also, bank loans in Europe were equal to $144 \%$ of GDP, compared with $45 \%$ in the US and $96 \%$ in Japan (European Banking Federation, 2011). ${ }^{2}$ These figures show how the European economy is indeed very heavily bank-oriented. Given the central role played by the banking system in the economy, European data offer an interesting case to investigate and enhance our understanding of the incentives that regulate bank risk-taking decisions.

We provide novel evidence on the level of diversification of large shareholders in the banking sector. We show that bank largest ultimate shareholders hold on average equity investments in thirteen different firms. ${ }^{3}$ Overall, $62 \%$ of shareholders hold investments in at least two companies and some of them $(23 \%)$ do so in ten or more. The average bank largest ultimate shareholder owns almost $41 \%$ (42\%) of the bank's total cash flow rights (voting rights), suggesting that, at least in Europe, shareholding in banks is not widely spread. This is consistent with Caprio et al. (2007) and Laeven and Levine (2009). It is thus reasonable to expect that bank largest ultimate shareholders are indeed able to exercise an element of control over the risk-taking choices of the banks they own. ${ }^{4}$ Interestingly, the correlation between portfolio diversification and total cash flow rights is only -0.2 , which suggests some caution in using ownership concentration as inverse proxy for portfolio diversification (similar figures are reported in Faccio et al., 2011).

Thanks to the large heterogeneity of our sample we proceed to investigate the role played by large shareholder portfolio diversification in bank risk-taking decisions. We use alternative proxies for portfolio diversification: 1) the total number of firms owned directly or indirectly by each bank largest shareholder (No. of firms); 2) the total number of different 3-digit US SIC sectors in which the largest shareholder invests (No. of sectors); 3) the total number of countries where the largest shareholder invests (No. of countries); 4) the Herfindahl Index of wealth concentration for each largest bank shareholder $(H I)$. The main proxy of bank risk-taking is the Inverse Z-score, which represents the probability of insolvency for each bank with at least five consecutive observations of data.

Our tests show that banks with more diversified shareholders tend to undertake riskier decisions. This result is also economically sizeable. Across all proxies of portfolio diversification, a standard deviation increase of portfolio diversification increases the insolvency rate of the average bank by almost $4 \%$. This figure compares very well with the average impact of all other control variables, around $4.8 \%$, suggesting that portfolio diversification is indeed a primary determinant of bank risktaking. This result is robust to alternative proxies of risk-taking, portfolio diversification, managerial

\footnotetext{
${ }^{2}$ The European Banking Federation collects banking sector data from its Members and Associates on an annual basis.

${ }^{3}$ Previous studies report an average of 2.4 stocks held by Finnish individuals (Karhunen and Keloharju, 2001), four to seven by the typical US individual investor (Barber and Odean; 2000, Goetzmann and Kumar, 2008), and about four by the average largest shareholder of non-financial companies in Europe (Faccio et al., 2011).

${ }^{4}$ In fact, all other shareholders hold on average only $4 \%$ of the Cash Flow Rights.
} 
ownership, bank type, and the inclusion of country characteristics that control for the regulations to assess the degree of capital at risk in a bank and to limit banks' non-lending activities.

As is common in many studies in our field, the relation we find could potentially be affected by endogeneity issues. We take a number of steps to control for the potential impact of this problem. First, in all our models we control for other bank-specific characteristics that are likely to affect risk-taking decisions, such as size, leverage, interest margin and interest activity, loan loss provision, listing status, and largest shareholder ownership. Further, the portfolio diversification proxies are taken at the year preceding the period over which we calculate bank risk-taking.

Second, we exploit the panel dimension of our sample and re-run the baseline models including shareholder fixed effects (besides year and country fixed effects), to control for the possibility of omitted variable bias. For instance, it may be argued that individual preferences of the largest shareholders may induce them to invest in banks with certain specific risk characteristics. If this were the case, then the causality would run from bank risk-taking to portfolio diversification, not the other way round. Panel data estimations with shareholder fixed effects show that even controlling for omitted variable bias, largest shareholder portfolio diversification still remains a statistically and economically important determinant of bank risk-taking.

Third, we adopt the instrumental variable (IV) technique as an alternative method to address the reverse causality issue. We use two different instruments that should capture the "natural" tendency of shareholders to diversify. After controlling for that, we still find that results are similar to the baseline models, that is, a positive and significant relation indicating that shareholders portfolio diversification leads to more bank risk-taking.

Fourth, we exploit the event of credit rating downgrade to control for potential reverse causality concerns. If reverse causality was likely to explain our previous results, then we would expect a significant change in shareholder portfolio diversification following a bank credit rating downgrade. Instead, we find that following a downgrade there appears to be no significant adjustment in the portfolio diversification of the largest shareholder.

We acknowledge that one cannot fully control for the endogeneity issue. Nonetheless, all our attempts form a consistent body of evidence that portfolio diversification of the largest shareholder leads to banks making decisions that carry a higher risk.

In the second part of the analysis, we study whether this stronger propensity to take on more risk has a positive (or negative) impact on the efficiency of capital allocation. A large body of literature shows that entrepreneur willingness to take risks is a key driver of economic growth (e.g. Acemoglu and Zilibotti, 1997; John et al., 2008). In this context, the primary role of banks would be to (efficiently) allocate capital to investors in the economy (Aghion and Howitt, 1997; Schumpeter, 1912, 1942; Tobin, 1989; Wurgler, 2000). Therefore, banks controlled by more diversified shareholders may provide loans to a riskier yet more profitable set of projects/borrowers so that more capital would be available to 
invest in growth opportunities. On the other hand, (excessive) risk-taking induced by diversified shareholders may also lead to investment in projects with negative net present value and, ultimately, hamper the allocation of capital in the economy.

We build on Wurgler's (2000) idea to measure the efficiency of capital allocation as the sensitivity of capital investment to the growth in value added. By using panel data estimations at regional level, we find that bank shareholder portfolio diversification does indeed have a significant impact on the efficiency of capital allocation. More importantly, it seems that banks controlled by diversified shareholders make allocation of capital more efficiently than banks controlled by shareholders with undiversified portfolios. In particular, a change in value added growth increases capital investment by approximately $9 \%$ of its mean in regions where banks are controlled by relatively undiversified shareholders, while it increases capital investment by almost $24 \%$ in regions where banks are controlled by shareholders with relatively diversified portfolio. These findings are robust to the inclusion of region and year fixed effects, internal cash flow, bank competition and financial development, shareholder types and alternative portfolio diversification measures.

This paper contributes to the existing literature on several levels. First, it complements previous studies on governance and banks decisions by documenting that: 1) bank largest shareholders are more diversified than investors in the non-financial market (holding equity stakes in thirteen different firms on average) and at the same time have sufficient cash flow rights (41\%) to control bank decisions; and 2) portfolio diversification has a strong direct effect on bank risk-taking decisions.

Second, it adds to the literature that investigates how concentrated wealth affects the economy in general (Morck et al., 2005). Within the banking system in particular, Morck et al. (2011) show how countries with banks tightly controlled by tycoons or families are more likely to allocate capital less efficiently and experience a higher level of instability. Findings in our paper show an alternative channel - that is, the degree of portfolio diversification of the largest shareholders - through which bank governance may positively affect the real economy.

Finally, this paper adds to the recent debate on how to improve bank risk governance. The publication of the Walker Report (2009) in the UK followed by those from the Basel Committee (2010b), the European Commission (2010), and OECD (2010) have highlighted two contrasting views, a shareholder-based approach on one hand, and a stakeholder-based approach on the other. The findings in this paper show that large shareholders play a non-trivial role in the risk-taking decisions of banks, which also has effects on the overall economy. There is no question that protection should be granted to all bank stakeholders, such as depositors and clients. Nonetheless, the incentives towards risk-taking by diversified shareholders seem to ultimately lead to improved capital allocation in line with the Schumpeterian view of "creative destruction". Therefore, in building the framework for a more efficient system of bank governance, a longer-term perspective should be properly taken into account. 
In the following section we describe the sample and our main variables. In sections 2 and 3 we present and discuss the main findings at bank- and macro-level respectively. Section 4 concludes the paper.

\section{Data}

Our primary source of data is Bankscope, one of the products of Bureau van Dijk, from which we gather information on both direct ownership and accounting variables for all European privately held and publicly traded banks with at least one year observation over the period 1999-2008. Bankscope is widely used by both academics and practitioners, including central banks (see, for example, Caprio et al., 2007; Demirgüç-Kunt and Huizinga, 2010; Laeven and Levine, 2009; Morck et al., 2011).

As for other Bureau van Dijk products, Bankscope is distributed in DVD format issued every month. We use one issue each year. As accounting information is typically incomplete for the year just ended and for the preceding year, we skip the most recent reporting year and collect accounting data retroactively from the 2010 DVD and move progressively backwards in time. ${ }^{5}$ Ownership information, on the other hand, is not provided on an historical basis. So we collect these data for each year from each DVD. Our sample starts from 1999 (as this is the first year for which we can collect ownership information with shareholders' identifiers), and ends in 2008.

To construct the equity portfolios of each bank largest shareholder, we first need to identify all ultimate shareholders. Bankscope includes worldwide ownership information of financial institutions only. However, a large number of banks are owned by non-financial companies (see, for example, Caprio et al., 2007). We therefore combine Bankscope with ownership data from the entire universe of the Amadeus Top 250,000 database. Amadeus provides both direct ownership and accounting data for both privately held and publicly traded European non-financial companies that satisfy a minimum size threshold. ${ }^{6}$ The quality of information in Amadeus Top 250,000 has been checked for both ownership and accounting data and more details are discussed in Faccio et al. (2011). Although Amadeus and Bankscope are products of the same provider, we went to great lengths to carefully check and harmonize the identifiers of shareholders across the two databases.

\subsection{Selection criteria}

We take several steps to carefully check and clean ownership information. First, we exclude those shareholders that are recorded both in Bankscope and Amadeus with a generic name (e.g.

\footnotetext{
${ }^{5}$ Further, the Bureau van Dijk team has confirmed that banks are never actually removed from Bankscope even when banks stop releasing financial accounts. This insures against the possibility of survivorship biases in the data. Nonetheless, the way we reassemble the panel dataset from each single DVD further addresses this potential concern.

${ }^{6}$ For France, Germany, Italy, Russia, Spain, Ukraine, and the UK, Amadeus includes all companies with revenues of at least $€ 15 \mathrm{~m}$, or total assets of at least $€ 30 \mathrm{~m}$, or at least 200 employees. For other countries, it includes all companies with operating revenues of at least $€ 10 \mathrm{~m}$, or total assets of at least $€ 20 \mathrm{~m}$, or at least 150 employees. The database excludes companies with operating revenues per employee or total assets per employee of less than $€ 1,000$.
} 
"Institutions", "Management", "Private shareholders") for which we cannot identify a specific individual/company. Nonetheless, we retain the company data and calculate the ultimate ownership for the remaining shareholders. Once we have the ultimate ownership of each shareholder, we exclude banks when the State is the largest ultimate shareholder, as state-owned banks have different risk-taking incentives than non state-owned banks (e.g. Caprio et al., 2007; De Nicoló and Loukoianova, 2007). ${ }^{7}$ Finally, we exclude banks controlled through cross-holding as it is problematic to identify the ultimate shareholder.

We further require that a bank has at least five years observations to compute both the $Z$-score and volatility of $R O A .{ }^{8}$ For the cross-sectional analysis, our final sample consists of 1,184 banks and 817 unique ultimate largest shareholders across 36 European countries. For the panel data analysis, we have a total of 4,768 bank-year observations, corresponding to 3,010 shareholders.

\subsection{Ultimate largest shareholders and portfolio diversification variables}

First, we identify the ultimate largest shareholder for each bank each year. That is, when we find that a bank is owned by another company (either financial or non-financial), we identify the owners of that company and so on until we cannot trace back any further. In a very simple pyramid structure, if shareholder A owns a fraction $x$ of company B, which owns in turn a fraction $y$ of bank $\mathrm{C}$, shareholder $\mathrm{A}$ then is identified as the ultimate shareholder of bank C. As in previous studies (e.g., Claessens et al., 2000; Faccio and Lang, 2002), we calculate the Cash Flow Rights of each ultimate shareholder as the product between links along the chain; and the Control Rights as the weakest link along the chain. In the small example above, the Cash Flow Rights of shareholder A in company $\mathrm{C}$ are equal to $C F_{A C}=x \times y$, while the Voting Rights are equal to $V R_{A C}=\min [x, y]$. We trace back pyramids of any length without imposing any cut-off threshold. Further, when we calculate the Cash Flow Rights and Voting Rights we account for the possibility that the ultimate shareholder controls a bank via a multitude of control chains. If we slightly modify the example above, allowing for shareholder A to hold also a direct fraction $z$ of bank C, then Cash Flow Rights of shareholder A become equal to " $(x \times y)+z$ ", and the Voting Rights become equal to " $(\min [x, y])+z$ ". We are not able to take into account the presence of dual class shares when we calculate the Cash Flow and Voting Rights of the largest ultimate shareholder. However, when we indirectly control for it, results are not affected (see the robustness tests section).

We use the entire universe of Bankscope and Amadeus Top 250,000 to track the ultimate shareholders of banks. The advantage of using this combined database is that we can trace the

\footnotetext{
${ }^{7}$ We use several key words to identify "State" shareholders, such as "State of", "City of" and "Ministry".

${ }^{8}$ To reduce the effect of outliers we winsorize all accounting variables at the bottom and top $1 \%$ of the distribution.
} 
ownership of publicly traded, privately held, financial and non-financial companies across several countries. $^{9}$

After having traced all ultimate shareholders, for each company each year we define the Largest Ultimate Shareholder as the ultimate shareholder with the highest Voting Rights.

We proceed then to construct our measures of portfolio diversification. In line with previous studies (e.g., Barber and Odean, 2000; Faccio et al., 2011; Goetzmann and Kumar, 2008; Karhunen and Keloharju, 2001), the main measure of portfolio diversification is the total number of equity positions that the Largest Ultimate Shareholder holds directly and indirectly across all samples each year (No. of Firms). This measure reflects a well-documented stylized fact in literature that the higher the number of stocks held in a portfolio the lower the idiosyncratic risk the investor bears and the better the overall portfolio diversification (e.g., Campbell et al., 2001; Merton, 1992; Statman, 1987). Nonetheless, it may be argued that this measure may overstate the true value of bank shareholders' portfolio diversification. For instance, if all companies in the portfolio belong to the same sector or operate in the same country, then the idiosyncratic risk of that portfolio is likely to increase. Therefore, we build two alternative proxies of portfolio diversification that may (partly) address this concern. We use a measure of sector diversification, defined as the number of different 3-digit US SIC code sectors included in each shareholder's portfolio (No. of Sectors); we also use a proxy for country diversification, defined as the number of different countries in which the shareholder holds equity investments (No. of Countries).

We acknowledge that our proxies of portfolio diversification may be geographically limited, as equity holdings of non-financial firms outside Europe are not included in Amadeus. Nonetheless, there is extensive evidence in the literature suggesting that investors often prefer to hold equities in domestic firms and exhibit "geographically-biased" equity portfolios ("Home bias puzzle" as described by French and Poterba, 1991; Cooper and Kaplanis, 1994; and Coval and Moskowitz, 1999). More recent findings show that this trend is still very strong even in countries with developed capital markets (Sorensen et al., 2007). ${ }^{10}$ To test how strong this potential bias is, we use the direct ownership information of all nonfinancial companies across 200 countries included in the Orbis database for 2008. With these data we reconstruct the equity holdings portfolios of our bank ultimate largest shareholders in that year and compare it with our (Bankscope- and Amadeus-based) measure of portfolio. The correlation between the two measures is $97 \%$ with a p-value of less than 0.01 , which suggests that the geographic limitation of our measure should not severely affect our estimations. Also, in the panel regression analysis we include shareholder fixed effects that, at least partially, should control for shareholder investment preferences.

\footnotetext{
${ }^{9}$ The drawback is that, given the size of this dataset, we are not able to identify members of the same family. So we treat each individual as a separate shareholder. In the second part of the paper we will define banks as "family-owned" if the ultimate largest shareholder is an individual.

${ }^{10}$ They calculate that at the end of $2003,70 \%$ of the UK total equity portfolio was in domestic equity; similarly for Spain (86\%), France (72\%), Italy (69\%), and Germany (66\%).
} 
A further source of concern could be that investments in (very) small (non-)financial companies not included in the combined database are also neglected. ${ }^{11}$ To reduce this potential shortcoming we use a measure of wealth concentration as an alternative proxy for portfolio diversification. In line with Bodnaruk et al., (2007), Demsetz and Lehn (1985), and Faccio et al (2011), we construct the Herfindahl Index of ownership concentration for each bank largest ultimate shareholder as follows:

$$
H I_{A}=\sum_{C=1}^{N} F W_{A C}^{2}
$$

where:

$$
F W_{A C}=\frac{B E_{C} \times C F_{A C}}{T W_{A}}
$$

and:

$$
T W_{A}=\sum_{C=1}^{N}\left(B E_{C} \times C F_{A C}\right)
$$

We define $\left(B E_{C} \times C F_{A C}\right)$ as the dollar value investment of shareholder $A$ in company $C$, which is the product between the book value of equity of company $C$ and the fraction of Cash Flow Rights of shareholder $A$ in company $C ; T W_{A}$ is the total portfolio value of shareholder $A$, proxy for the Total Wealth of shareholder $A ; F W_{A C}$ represents the fraction of wealth of shareholder $A$ invested in company C. ${ }^{12}$

The value of $H I$ ranges from 0 to 1 , where values closer to 1 indicate a higher degree of wealth concentration (lower portfolio diversification). Thanks to its "quick convergence property" (Adelman, 1969), using $H I$ reduces the potential issue of not including smaller firms in our shareholder portfolios, as smaller firms would have a minimal impact on the computation of HI. This measure should also reduce the concern that our main portfolio diversification proxy may overstate the true value of diversification.

As the distribution of No. of Firms is highly skewed, in our analysis we use Ln (No. of Firms) to limit the impact of extreme values. We apply the same transformation to the sector and country diversification measures. Finally, to make the interpretation consistent across all proxies of portfolio diversification, in the analysis we use $(1-H I)$ so that higher values of this variable indicate higher diversification.

\footnotetext{
${ }^{11}$ One further limitation is that we consider only investment in equity positions. Given the size of our sample, we are not able to retrieve information on investment in other assets such as bonds, real estate or cash.

${ }^{12}$ For non-financial firms the book value of equity is equal to the sum of "Shareholders Capital Funds" and "Other Shareholder Funds" as available in Amadeus. For banks, it is equal to "Total Equity" as reported in Bankscope.
} 


\subsection{Risk-taking proxy}

Consistent with several previous studies on banking (e.g., Boyd et al., 1993; García-Marco and Robles-Fernández, 2008; Laeven and Levine, 2009), our main proxy for bank risk-taking is the (inverse) Roy's Z-score. The advantage of this measure is that it does not rely on market values, something which is crucial for us given that our sample mainly includes privately held banks. The idea beyond the Zscore goes back to Roy (1952) and it relates to the "safety first" principle: an economic agent with uncertainty will optimize expected profits by choosing a level of assets and liabilities to minimize the probability of insolvency (that occurs when the value of assets is lower than the value of liabilities). Using the Bienaymé-Tchebycheff inequality, this has been translated into a measure of the distance to default defined as:

$$
P\left(\left|\pi-\varepsilon_{t}\right| \geq \pi-d\right)=P\left(\varepsilon_{t} \leq d\right) \leq \frac{\sigma^{2}}{(\pi-d)^{2}}
$$

where $\pi$ is the expected return of the assets; $\sigma$ is the standard deviation the returns of the assets; $\varepsilon_{t}$ is the random value of the return on the assets in period $t$, with mean equal to $\pi$, and standard deviation $\sigma$; $d$ is the "disaster level" or the level of liabilities that would trigger the default. The Z-score is interpreted as the number of standard deviations away from the mean of returns necessary to reach the agent's default level. In other words, it measures the agent's probability to be solvent. Bank insolvency is then defined as the state in which its losses $(-\pi)$ are greater than the value of its equity ( $E$, defined as the default level). Thus, we can rewrite Roy's score as $P(-\pi \geq E)=P(\pi \leq-E)$. If we substitute $\pi$ with bank return on assets (ROA) and $E$ with the value of bank equity relative to total assets (Capital Asset Ratio, $C A R)$, as in Laeven and Levine (2009), we obtain $P(\pi \leq-E) \equiv P(R O A \leq-C A R)$. The expression $-C A R$ is interpreted as the bank's leverage. So, the bank's probability of default is defined as:

$$
P(R O A \leq-C A R) \leq\left(\frac{\sigma_{i, R O A}}{R O A_{i}+C A R_{i}}\right)^{2} \equiv \frac{1}{\text { Zscore }_{i}}
$$

Inverse Z-score indicates that the probability of default depends on the relation between the bank's $i$ profitability $\left(R O A_{i}\right)$, the riskiness of its returns $\left(\sigma_{i, R O A}\right)$ and its existing level of capital reserves $\left(C A R_{i}\right)$. It represents the bank's exposure to operating losses that would reduce the buffer (capital reserves) against potential shocks to the returns (García-Marco and Robles-Fernández, 2008). This also measures the bank's risk-taking as riskier investment decisions increase the volatility of profits which in turn raises the probability of default.

For the cross-sectional analysis, the volatility of ROA $\left(\sigma_{i, R O A}\right)$ is the standard deviation of the ratio of gross pre-tax profit to total assets for each bank over the entire sample period (1999-2008), requiring at least five years of non-missing observations. Gross pre-tax profit is defined as the sum of pre-tax profit and loan loss provisions. Similarly, we calculate the average of $R O A$ and average of $C A R$ (defined as the ratio of equity to total assets) for each bank over the entire sample period. In the analysis 
we use the logarithm of the inverse of the Z-score (Ln. Inverse Z-score) to smooth the effect of extreme values.

\section{Results: portfolio diversification and bank risk-taking}

\subsection{Univariate analysis}

Table I reports country-level descriptive statistics of our sample. The final sample includes 1,184 banks across 36 countries, and at least one bank in each country. The countries with the most bank observations in the sample are Italy, France, Germany, UK, Spain and the Russian Federation. Most banks are privately held (76\%). Privately held banks do play an important role in the economic system. For instance, over the decade 2001-2010, privately held banks in the Euro area provided about $71 \%$ of the total loans of commercial banks. Similarly, in the UK they contributed an average of $60 \% .{ }^{13}$ It is therefore crucial to include privately held banks in our analysis to better understand the economic incentives that govern one of the most important players in the capital markets.

\section{[INSERT TABLE I HERE]}

Table II shows descriptive statistics of the main variables included in our analysis at shareholder, bank and region level. The average largest ultimate shareholder in our sample appears to be rather diversified, holding an equity portfolio of stocks from on average thirteen firms (median of two firms), in three different sectors and three different countries. Across the whole sample, $62 \%$ of shareholders hold stocks from at least two firms in their portfolio (Diversified dummy), 23\% from at least ten companies, and $7 \%$ from more than 50 companies. On the other hand, the wealth diversification (1-HI) of the average largest shareholder is equal to 0.20. A (1-HI) value of 1 indicates perfect diversification. So despite holding a fairly diversified portfolio, a large portion of the average largest shareholder's wealth seems to be concentrated in one (or a few) company. In fact, almost half seems to be invested in the bank controlled by the average largest shareholder (fraction of wealth almost equal to 54\%).

These figures provide new insights into bank shareholder characteristics that complement previous evidence. Previous studies have shown that the average investor is only moderately diversified: Barber and Odean (2000) and Goetzman and Kumar (2008) report that individual investors in the US hold an average of four different equity investments, while Faccio et al. (2011) show that shareholders of European non-financial companies hold equities in about four different firms. Further, Sullivan and Spong (2007) show in a limited sample of US state-chartered banks that between 1993 and 1994 average owner-managers invested $86 \%$ of their personal wealth in the bank they managed. Overall, our evidence seems to indicate that, on average, bank shareholders are more diversified than individuals and

\footnotetext{
${ }^{13}$ We use a number of sources to calculate these figures. First, from Bloomberg we collect data on total loans of all publicly traded commercial banks in the Euro area countries and the UK each year over the 2001-2010 period. Second, we gather data on total loans of all Euro area and the UK commercial banks from the European Central Bank Statistical Warehouse and the Bank of England, respectively.
} 
non-financial firms' shareholders, although a large fraction of their wealth seems to be concentrated in one company.

In addition, descriptive statistics in Panel B show that the average bank shareholder holds about $41 \%$ of Cash Flow Rights $(C F)$ and almost $42 \%$ of Voting Rights $(V R)$. These figures are higher than those provided in earlier studies on banking, possibly due to the inclusion in our sample of privately held banks. ${ }^{14}$ They suggest that the largest shareholder in our sample is indeed a powerful investor able to take decisions within the owned bank. Interestingly, the correlation between ownership (Cash Flow Rights) and diversification (No. of Firms) across all bank-year observations is only -0.2 , which implies that in our sample we may have shareholders with relatively diversified portfolios that hold a large fraction of ownership in a single bank, and vice versa. This is in line with Faccio et al. (2011), who caution researchers about using ownership concentration as a perfect proxy for portfolio diversification.

Finally, we observe large heterogeneity in the main risk-taking measure. Untabulated figures show that Z-score varies from 324 (highly stable banks) to 3 (very insolvent banks). An average Z-score of 37 means that a bank's profits would have to decrease 37 times their standard deviation before breaching the bank's default level. Thus, the higher the Z-score, the lower the Inverse Z-score and the less risky the bank. These figures are comparable to those reported in earlier studies (e.g., Garcia-Marco and Robles-Fernándes, 2008; Laeven and Levine, 2009).

\section{[INSERT TABLE II HERE]}

\subsection{Multivariate analysis}

For the main analysis we estimate the following cross-sectional model:

$$
\left(\frac{1}{\text { ZScore }}\right)_{i}=\alpha+\beta(\text { Portfolio Diversification })_{i}+\sum_{j=1}^{J} \gamma_{j} X_{i j}+\text { Country } F E+\text { Year FE }+u_{i}
$$

All independent variables are taken at the beginning of the year from which we calculate the Inverse Zscore, so that we have one observation for each bank. (Portfolio Diversification) $i$ represents one of our four measures of portfolio diversification. $X_{i j}$ is a vector of $j$ control variables for each bank $i$ that includes: 1) Cash Flow Rights of the ultimate largest shareholder; 2) bank size, measured as the natural logarithm of total assets (Ln. Total Assets), which is also proxy for a bank's ability to diversify its risks (e.g., Boyd and Runkle, 1993); 3) bank leverage, defined as the ratio of equity to total assets (CAR); 4) Net Interest Marginal Revenue, defined as the ratio of the difference between interest income and interest expenses to the interest income, which is a proxy of the profit margin (franchise value) of the bank (Hellman et al., 2000; Keeley, 1990); 5) Interest Activity, measured as the ratio of interest income to total operating income, which should capture the degree of interest-generating banking activities

\footnotetext{
${ }^{14}$ Based on Faccio and Lang (2002) data, in Western European countries the average cash flow rights (voting rights) of the largest ultimate shareholder of financial companies at 10\% cut-off are 31\% (35\%); while Laeven and Levine (2009) report $20.5 \%(29.6 \%)$.
} 
relative to non-traditional banking activities (e.g., trading fees, non-deposits funding), and therefore, the level of specialisation of each bank; ${ }^{15}$ 6) Loan Loss Provisions, defined as the ratio of loan loss provisions to interest income, which is a proxy for credit quality and monitoring costs (Allen et al., 2011; Allen and Gale, 2004; Boyd and De Nicoló, 2005); 7) Private dummy, equal to one if a bank is privately held and zero otherwise, which should capture differences in risk-taking preferences between privately held and publicly traded banks (Barry et al., 2011). All regressions include country fixed effects (Country FE) that should capture all the time-invariant country unobservable characteristics likely to affect the risk-taking decisions of banks within each country. We include also time dummies as banks may have entered our sample at different points in time. Standard errors are robust to heteroskedasticity.

Table III reports results of the cross-sectional analysis. The evidence is robust across all proxies of portfolio diversification: banks with more diversified largest shareholders tend to undertake more risk (higher probability of default). Further, this relation is not only statistically significant (p-values $<0.05$ ), but also economically sizeable - a standard deviation change across all proxies of diversification is likely to increase the Inverse Z-score of the average bank by almost $4 \%$. This effect is remarkable if compared with the average impact of the other control variables. For instance, in column (1) the average impact across CAR, Net Interest Marginal Revenue, Interest Activity, and Loan Loss Provisions is 4.8\%.

As for the control variables, most of them show the expected sign. On one hand, Net Interest Marginal Revenue is negatively associated with risk-taking, consistent with the idea that banks in very concentrated markets increase their profitability up to the point of mitigating the risk-taking incentives of their shareholders (Hellman et al., 2000; Keeley, 1990). On the other hand, Loans Loss Provisions and Interest Activity relate bank risk-taking to the banks' activities. In particular, Loans Loss Provisions is positively related to bank risk-taking, as higher (lower) monitoring costs (credit quality) increase the risk of lending. Interest Activity is inversely related to risk-taking, since those banks with a higher proportion of traditional interest-earning banking activities (i.e. interest deposits, mortgage lending) are able to implement more conservative portfolio choices (Demirgüç-Kunt and Huizinga, 2010).

Interestingly, the ownership of the largest shareholder (Cash Flow Rights), although showing the same sign of portfolio diversification, is not significant in three out of four models and its impact is substantially lower than all portfolio diversification measures. This is further evidence that portfolio diversification does indeed enhance our understanding of risk-taking decisions in banks.

[INSERT TABLE III HERE]

\footnotetext{
${ }^{15}$ Banks engaging in non-traditional activities often tend to take on more risks (Demirgüç-Kunt and Huizinga, 2010). We therefore expect a negative relation between bank risk-taking and Interest Activity.
} 


\subsection{Endogeneity issues}

Although appealing, results in the baseline analysis may suffer from endogeneity issues that could bias the direction of causality between risk-taking and portfolio diversification measures. We therefore undertake a number of steps to minimize these concerns.

\subsubsection{Omitted variable bias}

It is well known in literature that optimal financial decisions of investors are "derived from individual and exogenously specified preference functions" (Merton, 1992). In our analysis we are able to control for two main shareholder features, namely, the degree of diversification of equity portfolio (i.e., wealth concentration) and the ownership held in a specific bank. However, preferences may still differ across shareholders with similar observed characteristics, due to other traits that are not observed (e.g., age, total non-equity wealth) or to features that are unobservable (e.g. particular forms of the utility function). Omitting such variables may render all explanatory variables in our regressions biased and inconsistent (Wooldridge, 2002).

Therefore, we exploit the panel dimension of our database and use panel data analysis that allows us to include bank shareholder fixed effects. This helps to control for the potential omitted variable bias due to shareholder risk-taking incentives not captured by portfolio diversification. This is a unique advantage we have over previous studies in banking that, due to data limitations, were able to exploit only the cross-sectional heterogeneity of shareholders characteristics (e.g., Gorton and Rosen, 1995; Laeven and Levine, 2009; Sullivan and Spong, 2007).

We estimate the following model:

$$
\begin{gathered}
\left(\frac{1}{Z \text { Score }}\right)_{i,(t, t+4)}=\alpha+\beta(\text { Portfolio Diversification })_{i, t-1}+\sum_{j=1}^{J} \gamma_{j} X_{i j, t-1}+ \\
+ \text { Shareholder FE + Country FE }+ \text { Year } F E+u_{i, t-1}
\end{gathered}
$$

where we calculate each component of the Inverse Z-score $\left(\sigma_{i, R O A}, R O A\right.$ and $\left.C A R\right)$ over five consecutive year overlapping periods, that is, 2000-2004, 2001-2005, 2002-2006, 2003-2007 and 2004-2008.

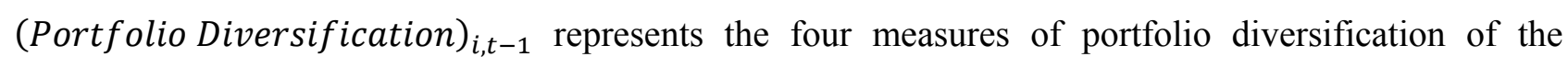
largest shareholder in each bank at the beginning of each overlapping period. $X_{i j, t-1}$ is a vector of all control variables taken at the beginning of each overlapping period. Besides shareholder fixed effects (Shareholder FE), we include country (CountryFE) and time fixed effects (Year FE). Standard errors are robust to heteroskedasticity.

Table IV reports the panel data estimates. After controlling for potential omitted variable bias, our findings suggest that a change in portfolio diversification effects a significant change in bank risktaking behaviour. In particular, the more diversified shareholders of a bank are, the more the solvency level of the bank seems to deteriorate. These results further support our previous findings and their 
economic impact, although slightly lower, are still very important. For instance, a standard deviation increase in ( $\operatorname{Ln}$ No. of Firms) is likely to increase the insolvency ratio of the average bank by $3.1 \%$. (Comparatively, the average economic impact across all other control variables in the same model is $3.8 \%)$.

\section{[INSERT TABLE IV HERE]}

\subsubsection{Reverse causality}

Reverse causality implies that changes in a bank's decisions will affect its shareholders' investment strategies. For instance, the bank's largest shareholders may increase (decrease) the level of diversification of their portfolios following a shock that raises (lowers) the risk profile of the bank they own. We would still observe a positive relation between risk-taking and portfolio diversification, as in our main findings. However, the causality would run from bank risk-taking decisions to portfolio diversification, not the other way round. An alternative channel for reverse causality could be that a shareholder planning to invest in a bank with a certain risk profile would accordingly make portfolio diversification adjustments in advance. We adopt two different strategies to control for this potential issue.

First, we adopt the classic instrumental variable (IV) technique to address the potential reverse causality issue in the baseline models. We use the Average Diversification of all other bank shareholders in the same region and the same year, where the bank is headquartered to extract the "natural" tendency to diversify across investors within the same geographical area. The richness of our database allows us to exploit the cross-sectional variation of shareholder ability to diversify portfolio across European regions. This measure is close in spirit to Laeven and Levine (2009) and Faccio et al. (2011). It seems unlikely that the average diversification of shareholders investing in other banks in the same region of the bank of interest has any direct impact on the risk-taking decisions of that bank. ${ }^{16}$ Bankscope provides information also on the address where banks have their headquarters. We use the postcode to identify the region of each bank. When not available, we use the name of the city. We then compute the average for each proxy of our portfolio diversification measures in each region each year.

Table V Panel A reports the results of the second-stage regressions that include the predicted values of portfolio diversification proxies estimated in the first stage. For the first-stage regressions we report only the estimates of the instrumental variables (first-stage regressions include also all other control variables). Across all models Average Diversification is significantly correlated to each proxy of portfolio diversification, with the expected sign. Further, both the values of the F-tests of the excluded instruments (ranging from 51.42 to 92.55) and the values of the partial R-squared of excluded instruments not close to zero indicate that these are good instruments (Bound et al., 1995, and Staiger and Stock, 1997, show that a value of the first-stage $F$ statistics below 10 and the R-squared close to

\footnotetext{
${ }^{16}$ The definition of region is based on the Eurostat NUTS (Nomenclature of Territorial Units for Statistics). Examples of region are "North West", "East Midlands", "London" and "Wales" in the U.K; or "Lombardia", "Piemonte" and "Toscana" in Italy.
} 
zero are suggestive of weak instruments). Most importantly, all estimated coefficients of portfolio diversification in the second-stage regressions are still positive and statistically significant.

A potential criticism of the above instruments is that they may capture the financial development within each region that directly and indirectly could affect the risk-taking decisions of the bank of interest (e.g., regions where the stock markets are headquartered offer more developed financial services that may create further opportunities for banks to undertake risky decisions). Therefore, as a robustness test we construct an alternative instrument based on the UK sample alone and we re-run the same IV regressions on the Euro area countries in our database.

The intuition behind this test is that the UK, having such a highly developed stock market, is possibly the least bank-oriented economy in Europe and is also not regulated by the European Central Bank. ${ }^{17}$ Therefore, the financial development of the UK market should not directly affect the risk-taking of banks in the Euro area countries. To relate the degree of diversification of UK shareholders to European ones, we use the geographic distance of each bank from the main stock market within each country.

Therefore, we calculate the geographic distance between each UK bank and London's capital markets, and then for each quintile of this geographic distance distribution we calculate the Fraction of Diversified Shareholders of banks that are included in each quintile. ${ }^{18}$ We use this variable for each European bank that has a similar geographic distance from the main stock market in the country where it is headquartered. Results in Panel B confirm the positive and significant impact of shareholder diversification on bank risk-taking decisions.

\section{[INSERT TABLE V HERE]}

Second, we exploit the event of a bank credit rating downgrade as a shock that is likely to affect risk-taking. If there is a feedback effect from risk-taking to portfolio diversification, then after the downgrade and the change in risk-taking, we should observe a change in the portfolio diversification of the bank largest shareholder.

To identify downgrades in credit rating, we use the Fitch Long Term Senior-Debt credit ratings from 2001 to 2006 as provided by Bankscope. Since we aim to capture only idiosyncratic shocks to bank risks, we exclude the years of the sub-prime financial crisis that most likely had an effect on both bank risk-taking decisions and shareholder portfolio diversification simultaneously. We define a downgrade event as being when a bank in a certain year experiences a negative change of at least one notch from its previous rating. The initial sample of banks with at least two reported credit ratings between 2001 and 2006 is 2,025. We identify 615 downgrade events. Finally, we require banks to have

\footnotetext{
${ }^{17}$ The size of financial sector is defined as the sum of the stock market capitalization, bank credit to the private sector and debt securities issued by the private sector, divided by GDP. For instance, the European Central Bank (2012) has calculated that over the $2005-2010$ period, this ratio is $270 \%$ for the Euro area countries; while it is $411 \%$ for the UK only.

${ }^{18}$ We use longitude and latitude data to calculate the spherical distance between the two, as in Dass and Massa (2009).
} 
available information on Inverse Z-score and No. of Firms one year before and after the downgrade event. We are left with a total of 57 instances.

Table VI reports results of the tests of difference in means for both Inverse Z-score and No of Firms portfolio diversification before and after the downgrade. We observe a significant increase in insolvency (risk-taking) after the downgrade, from 0.110 to 0.193 in the Inverse Z-score with a p-value of less than 0.01. However, when we turn to the change in portfolio diversification, the largest shareholders do not seem to increase the level of diversification of their portfolios significantly. The $\mathrm{p}$ value of the change in No. of Firms, from 25.085 to 25.359 , is around 0.98 .

One could argue that largest shareholders would preventively adjust their portfolio diversification in anticipation of the downgrade event. This would imply no change in portfolio diversification afterwards, as this change already occurred before the downgrade. To rule out this possibility, we look for those instances where portfolio diversification is available further back in time and we calculate the change in the average portfolio diversification in the two years before the event. Although this reduces the sample to 23 cases, we find no significant change (p-value around 0.33 ), further suggesting that there are no feedback effects from risk-taking to portfolio diversification decisions.

\section{[INSERT TABLE VI HERE]}

\subsection{Further robustness tests}

Table VII reports results from a number of additional robustness tests.

Alternative dependent variables. We use two alternative proxies for risk-taking as dependent variable: volatility of ROA $\left(\sigma_{i, R O A}\right)$ alone and Survival. Volatility of ROA is commonly used in the literature as a proxy for firm risk-taking decisions (Faccio et. al., 2011; John et al., 2008). For the cross-sectional analysis, the volatility of ROA $\left(\sigma_{i, R O A}\right)$ is the standard deviation of the ratio of gross pre-tax profit to total assets for each bank over the entire sample period (1999-2008), requiring at least five years of non-missing observations. In the estimations we use its logarithmic transformation to smooth the effect of extreme values. Survival is a dummy equal to 1 if a bank, entering our sample between 1999 and 2004, is still in the sample for at least five years, and zero otherwise. In column (1) we report the results from the cross-sectional analysis with volatility of ROA as dependent variable. The estimated coefficient of portfolio diversification is positive and statistically significant. In column (2) we show the results of the Logit regression where Survival is the dependent variable. Banks controlled by more diversified shareholders are less likely to survive, where the average probability of survival in our sample is equal to $70 \%$.

Portfolio diversification measures. We run three different tests to control for the robustness of our portfolio diversification measures. First, we replace our measures of portfolio diversification with a 
binary variable equal to one if the portfolio of the largest shareholder holds stocks from at least two companies and zero otherwise. Results in column (3) are qualitatively similar to the baseline findings.

Second, as mentioned above, we are not able to take into account the presence of dual class shares in our calculations of the ultimate largest shareholders. This potentially creates a measurement error in the identification of (ultimate) controlling owners and, therefore, in the construction of our portfolio diversification proxies. However, previous studies show how the "dual class shares" mechanism to separate cash flow from voting rights has been extensively adopted in only a very few European countries (Faccio and Lang, 2001; Nenova, 2003). Further, a report by the European Commission (2007) documents that an increasing number of firms in continental Europe have recently unified their shares into a single class. Based on a study by Pajuste (2005), in only four countries (of our sample) do more than $20 \%$ of publicly traded companies still seem to use such a mechanism at the end of 2001: Sweden (46.3\%), Denmark (36.6\%), Italy (34.6\%), and Finland (23.9\%). We believe that this should not have an impact on our results. Nonetheless, we analyse again the impact of portfolio diversification on bank risk-taking accounting for this potential bias. As there is no evidence on the extent of dual class shares use among private companies, in general, and banks in particular, we conservatively assume that public firms' use of dual class shares mirrors that of private firms (as in Lyandres et al., 2013). We therefore exclude the countries above from our sample and re-run the baseline model. Results in column (4) are similar to our previous findings.

Third, a further limitation of our portfolio diversification measures is that we are not able to capture indirect equity investments (e.g. through mutual funds). One could argue that this may bias our measures downwards, in particular in those markets where the presence of mutual and hedge funds is as pervasive as in the US market. However, Lyandres et al. (2013) show how similar measures of portfolio diversification for controlling shareholders of non-financial companies are not affected by this issue. Further, Ferreira and Matos (2008) show that institutional investors (mutual funds) hold on average less than $20 \%$ (4\%) of the fraction of market capitalization in Europe. These figures are substantially higher in the US market, $66 \%$ and $18 \%$ respectively. We therefore think that this should not have any strong impact on our evidence. Nevertheless, based on Ferreira and Matos (2008) we exclude those countries in the top tertile of the institutional investors holding distribution: Sweden (33.8\%), Finland (33.8\%), Netherlands (32.4\%), and Ireland (30.5\%). Findings in column (5) are similar to the previous results.

Managerial ownership. We further control for managerial incentives proxied by the fraction of shares held by all managers in each bank each year. Bankscope provides the full names and positions of all directors in the board for each bank each year. Therefore, to retrieve their ownership information, we search for each director's name in the complete list of direct shareholders of each bank each year. We then sum all the equity holdings for all manager-shareholder matches (Managerial Ownership). When we cannot find a proper match, we use the ownership data of those shareholders recorded in Bankscope with a generic name that directly relates to a director ownership position (e.g. "Management", 
"Executives", "Board members"). We use this information as the managerial ownership of that bank that year. We replace Managerial Ownership with a zero when we cannot retrieve this information any further. Results on the augmented baseline model are included in column (4). Managerial Ownership is positive and significant, consistent with previous evidence (e.g., Saunders et al., 1990). This evidence, however, does not change the effect of portfolio diversification on risk-taking, which remains strongly significant (column 6). ${ }^{19}$

Large shareholding. Previous studies take $10 \%$ of voting rights as a threshold to identify large, powerful shareholders who are able to influence a bank's decisions (Caprio et al., 2007; Laeven and Levine, 2009). In our sample, the average (median) ultimate largest shareholder holds almost $42 \%$ (30\%) of voting rights, suggesting that most of our banks are controlled by powerful shareholders. Nonetheless, we re-run the baseline model excluding those banks where the ultimate shareholder holds less than $10 \%$ of voting rights. Results hold as reported in column (7). Untabulated findings are similar when we exclude shareholders with a voting rights threshold of $20 \%$.

Bank type. We control also for bank type. Previous studies show that commercial banks tend to take more risks than other types of banks, such as saving banks (see, for example, Garcia-Marco and RoblesFernandez, 2008). This has been mainly related to a difference in ownership structure, which we already control for. Nonetheless, we include a binary variable equal to one if a bank is a commercial bank and zero otherwise. Most of banks in our sample are commercial banks (66\%). Results in column (8) show that commercial banks do indeed tend to undertake more risks than others. However, this does not affect the impact of portfolio diversification.

Institutional settings. Previous studies include a number of national regulations aimed at reducing excessive risk-taking incentives of bank shareholders. For instance, regulations in some countries are more restrictive than others in the assessment of the capital at risk in the bank or in limiting bank nonlending activities, such as market, insurance or real estate activities (e.g., Caprio et al., 2007; Laeven and Levine, 2009).

Further, previous studies show that stronger creditor rights are positively related to higher risktaking by banks, mainly due to the fact that banks tend to lend to a wider set of (riskier) borrowers (Djankov et al., 2007; Houston et al., 2010). At the same time, better information-sharing among creditors should alleviate the ex-ante adverse selection problem in loan screening (Houston et al., 2010).

All our previous tests include country fixed effect that should already control for the potential influence of such characteristics. Nonetheless, we re-run our baseline model augmented with two proxies for bank regulations as in Barth et al. (2004) and Laeven and Levine (2009): 1) a Capital Stringency Index that measures the regulatory approach to assessing the degree of capital at risk in a

\footnotetext{
${ }^{19}$ We also control for the identity of the controlling shareholders. In our baseline model we include a binary variable equal to one if the largest shareholder is an individual (family) and zero otherwise. Unreported tests show that there is no significant difference across types of shareholders, contrary to the findings of Barry et al., (2011). This is probably due to our portfolio diversification measure that already captures the risk-taking incentives of different groups of shareholders.
} 
bank; and 2) a Restrict Index, which measures the regulatory barriers for banks to undertake non-lending activities. $^{20,21}$ We further include the Creditor Rights Index from La Porta et al. (1998) and the Depth of Credit Information from Djankov et al. (2007), which measures the information contents of the credit information. $^{22}$

Finally, accounting-based risk-taking proxies are likely to be subject to potential criticism of earnings manipulation and differences in accounting standards across countries. Although we use Survival as an alternative measure of risk-taking to limit this concern, we further control for the quality of the accounting standards by augmenting the baseline model with the Financial Statement Transparency from Barth et al. (2006), which measures the transparency of bank financial statement practices. Higher values indicate more transparency. ${ }^{23}$

Results when controlling for bank regulations and accounting standards, in column (9), are in line with previous evidence (Houston et al., 2010; Laeven and Levine, 2009) while Creditor Rights and Depth of Credit Information have no significant impact. More importantly, even after controlling for national regulations and potential accounting manipulation, the effect of portfolio diversification is still positive and highly significant, as in our main findings.

Non-Eastern European banks. One further concern is the inclusion of Eastern European banks in our sample. Recently, Eastern European banks have experienced a period of intense privatisation and restructuring and a dramatic growth in lending to private sector that certainly have influenced their risktaking behaviour (Cottarelli et al., 2005; Lipton et al., 1990). Further, relatively weaker accounting disclosure requirements could make data on Eastern European banks noisier than the rest of our sample. Although the inclusion of country fixed effects should control for this potential issue as well, we nonetheless re-run the baseline model after excluding these countries. Findings in column (10) on Western European banks confirm our main hypothesis, providing further evidence of the positive and significant relation between portfolio diversification of bank shareholders and bank risk-taking.

\section{[INSERT TABLE VII HERE]}

\footnotetext{
${ }^{20}$ Those studies also used a dummy for the presence of deposit insurance and the minimum capital requirement in each country. We cannot use these two variables here as (when available) they take the same values across all countries in our sample.

${ }^{21}$ The Capital Stringency Index is based on the following questions: Is the minimum capital asset ratio requirement risk weighted in line with the Basel guidelines? Does the minimum ratio vary as a function of market risk? Are market values of loan losses not realized in accounting books deducted from capital? Are unrealized losses in securities portfolios deducted? Are unrealized foreign exchange losses deducted? What fraction of revaluation gains is allowed as part of capital? Are the sources of funds to be used as capital verified by the regulatory or supervisory authorities? Can the initial disbursement or subsequent injections of capital be made with assets other than cash or government securities? Can initial disbursement of capital be made with borrowed funds? The Restrict Index measures the extent to which banks are allowed by the regulator to engage in securities market activities (e.g., underwriting, brokering, dealing, and all aspects of the mutual fund industry), insurance activities (e.g., insurance underwriting and selling), real estate activities (e.g., real estate investment, development, and management), and the ownership of nonfinancial firms (Barth et al., 2004).

${ }^{22}$ The Depth of Credit Information measures the availability of credit information from either a public registry or a private bureau to facilitate lending decisions. It ranges from 0 to 6 with higher values indicating more credit information available.

${ }^{23}$ As an alternative we also use the Accounting Standards index from La Porta et al. (1998). Results do not change.
} 


\section{The role of portfolio diversification in capital allocation efficiency}

The role of financial intermediaries (banks) to allocate capital in the economy has been extensively discussed by a vast literature that dates back to 1873 when Bagehot argued that the financial system in England:

\section{[...] could make capital run as surely and instantly where it is most wanted, and where} there is most to be made of it, as water runs to find its level [...] (Bagehot, 1873, p.13).

Similarly, Schumpeter described the banker as one who:

[...] stands between those who wish to form new combinations and the possessors of productive means.... He makes possible the carrying out of new combinations, authorises people, in the name of society as it were, to form them. He is the ephor of the exchange economy. (Schumpeter, 1934, p.74).

Numerous theoretical and empirical studies agree that the unique advantage of banks of being able to acquire and process information improves the ex-ante assessment of growth opportunities. This in turn makes the allocation of capital more efficient (e.g., Boyd and Prescott, 1986; Diamond, 1984; Wurgler, 2000).

Some of these works have also looked into the internal organization of banks and noted that the governance of the banking system is indeed important in shaping the ability of banks to allocate capital in the economy. If wealth is concentrated in the hands of a small number of elites, it can bias capital allocation and retard growth (see Morck et al., 2005 for an extensive survey). In particular, certain categories of bank shareholders, such as families and the Government, seem to correlate with more inefficiency (e.g., La Porta et al., 2002; Morck et al., 2011; Taboada, 2011; Wurgler, 2000).

More generally, in systems with poor investor protection where wealth tends to be concentrated, the conservative (risk averse) choices of insiders have been reflected in inefficiency at the economy level, for example through worse capital allocation (Wurgler, 2000) or slower growth (John et al., 2008). Compared to undiversified shareholders, more diversification at shareholder level may imply a better allocation of capital. Banks controlled by more diversified shareholders may be induced to provide loans to a riskier yet more profitable set of projects/borrowers so that more capital would be available to invest in growth opportunities. This would be in line with the idea of an efficient allocation of capital. On the other hand, one could argue that (excessive) risk-taking induced by diversified shareholders may also lead to investment in projects with negative net present value that, ultimately, hinders the efficient allocation of capital in the economy. Building on these considerations, we take one step further and investigate whether the portfolio diversification of bank shareholders has any impact on the allocation of capital in the economy. The advantage we have over previous studies is that we can identify a further channel through which developed financial markets and legal institutions may impact the capital allocation procedure, that is, shareholder portfolio diversification. 
To measure the efficiency of capital allocation we exploit the basic idea from Wurgler (2000). He argues that for the capital allocation process to be more efficient, firm-level investment should increase in those sectors with faster value added growth and decrease in those with declining opportunities. Value added growth is here taken as a proxy for growth opportunities. We therefore use the sensitivity of capital investment to the growth in value added as a measure of the efficiency of capital allocation and we investigate whether this sensitivity increases in the presence of banks controlled by more diversified shareholders.

\subsection{Data and variables definitions}

We conduct this analysis at regional level to establish a more direct link between capital allocation and portfolio diversification of institutions headquartered in the same region. A number of studies show how geographical distance between banks and borrowers is indeed an important factor that facilitates the ex-ante collection and use of soft private information by banks (e.g., Agarwal and Hauswald, 2010; Degryse and Ongena, 2005; Petersen and Rajan, 2002). This may have in turn an impact on the efficiency of capital allocation of firms as well.

We aggregate both firm- and bank-level data at regional level each year to construct measures of regional capital investment, value added growth, and portfolio diversification. ${ }^{24}$

We gather information on capital investment and value added at firm level from Amadeus Top 250,000. Amadeus, like Bankscope, provides information on the address where companies have their headquarters. As in the previous analysis, we use the postcode to identify the region of each firm. When not available, we use the name of the city. To be included in our analysis we require: 1) firms from Amadeus to have both accounting and geographical information for at least one year in the period 1999 to 2008 ; 2) banks to have largest shareholder portfolio diversification, accounting and geographical information for at least one year in the period 1999 to 2008. The final sample counts 692,096 nonfinancial firm-year observations and 8,683 bank-year observations across 124 unique regions. ${ }^{25}$

To implement our analysis we modify the simple version of Wurgler's (2000) elasticity model by including our measure of portfolio diversification and its interaction with value added growth. Specifically, we estimate the following model:

$$
\begin{aligned}
& \frac{\Delta \text { Gross } P P E_{r, t}}{\text { Total Fixed } \text { Assets }_{r, t-1}}=\alpha+\eta\left[\ln \left(\frac{V_{r, t}}{V_{r, t-1}}\right)\right]+ \\
& +\delta(\text { Portfolio Diversification })_{r, t}+\theta\left[\ln \left(\frac{V_{r, t}}{V_{r, t-1}}\right)\right] \times(\text { Portfolio Diversification })_{r, t} \\
& + \text { Region } F E+\text { Year } F E+v_{r, t}
\end{aligned}
$$

\footnotetext{
${ }^{24}$ We aggregate data on capital investment, value added and portfolio diversification by calculating the simple average of all observations located in each region each year (similar to the methods of Gennaioli et al., 2012).

${ }^{25}$ Countries included in this analysis are: Austria, Belgium, Bulgaria, France, Germany, Hungary, Italy, Netherlands, Norway, Poland, Spain, Sweden, and the UK. These cover more than $72 \%$ of our initial sample.
} 


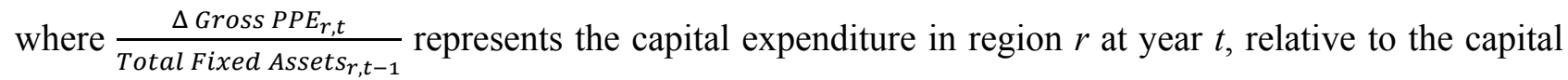
stock; $\ln \left(\frac{V_{r, t}}{V_{r, t-1}}\right)$ is the value added growth in region $r$ at year $t$ computed as the natural $\log$ of the

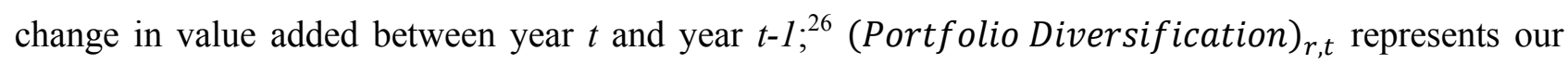
main measure of portfolio diversification (the natural log of the total number of firms owned directly or indirectly by each bank largest shareholder) in each region $r$ at time $t$. As a robustness test, we also use our measure of wealth diversification (1-HI) in each region $r$ at time $t . \eta$ represents Wurgler's elasticity measure: the parameter should capture the elasticity of changes in gross fixed capital formation in each region to changes in value added. The magnitude of this elasticity is interpreted as the speed at which capital supply adjusts to changes in firms' productivity: the higher the elasticity the more efficient the capital allocation, as the capital flows where the growth opportunities are. $\theta$ is our coefficient of interest, which measures the impact of bank shareholder portfolio diversification on the investment sensitivity to growth opportunities. If portfolio diversification is irrelevant to capital allocation efficiency, then $\theta=0$. All regressions include region fixed effects that should control for any other region/institutional characteristic that could affect capital allocation, and year fixed effects. Standard errors are robust to heteroskedasticity.

\subsection{Multivariate analysis}

Across all models (Tables VIII and IX), findings are consistent and seem to suggest that portfolio diversification of large shareholders of banks in a certain region has a significant impact on the capital allocation efficiency of firms. More importantly, our results indicate that capital appears to be allocated more efficiently in regions where banks are controlled by (more) diversified shareholders. In fact, the interaction term between value added growth and portfolio diversification proxies is always significant with a p-value less than 0.05 across all models. This effect is also economically important when we evaluate the partial derivative of capital investment with respect to value added growth at different levels of portfolio diversification. For instance, in Table VIII column (1), for regions where banks are controlled by undiversified shareholders, the interaction term drops out (since the natural log of one is equal to zero) so the effect of value added growth on capital investment is 0.26 (the coefficient on the standalone value added growth variable). For regions where banks are controlled by shareholders with average portfolio diversification (natural $\log$ of 16.5 is 2.8, Table II Panel C), the overall effect increases to 0.42 (that is, $0.26+[0.058 \times 2.8]$ ) with a p-value of less than 0.001 .

These figures imply that a one standard deviation increase in value added growth increases capital investment by approximately $9 \%$ of its mean in regions where banks are controlled by

\footnotetext{
${ }^{26} \triangle$ Gross PPE, is the annual change in net Total Fixed Assets, with depreciation added back; Total Fixed Assets is the sum of tangible fixed assets, intangible fixed assets, and other fixed assets (all net of accumulated depreciation). Value added, in constant US dollars (year 2000 prices), is defined as earnings before interest and taxes plus the cost of employees.
} 
undiversified shareholders (that is, [0.26 x 0.129]/0.372). The same standard deviation increase in value added growth in regions where banks are controlled by shareholders with average portfolio diversification increases capital investment by almost $24 \%$ of its mean (that is, $[0.42 \times 0.129] / 0.372$ ). Findings in column (2) report similar results when we use the wealth diversification measure $(1-H I)$ as an alternative proxy for portfolio diversification.

\section{[INSERT TABLE VIII HERE]}

The relation that these findings seem to suggest, however, may well be affected by endogeneity issues that could hamper the direction of causality and so their interpretation. For instance, capital investment may cause contemporaneous changes in value added. More importantly, more diversified shareholders may cluster in more productive regions. We believe that our results cannot be so easily explained away by endogeneity concerns. First, there are several studies showing that capital gestation lag ranges between one and two years (e.g., Koeva, 2000; Krainer, 1968; Mayer, 1960) and it takes at least four quarters for investment to respond to technological shocks (Millar, 2005). Second, a considerable amount of evidence from finance and growth literature indicates that financial development does indeed spur economic development rather than the other way around (see Levine, 2005, and Morck et al., 2011, for extensive surveys on this aspect). For instance, developed financial sectors increase investment more in growing industries, and decrease investment more in declining industries, by reducing the wedge between the price of external and internal finance (e.g., Rajan and Zingales, 1998, 2003; Wurgler, 2000). Similarly, Neusser and Kugler (1998) find that generally finance boosts capital allocation. Further, we exploit the panel dimension of our database and we include region fixed effects to control for potential omitted variable bias.

With these caveats in mind, our tests point towards a similar conclusion, that is, financial development in the form of bank shareholders portfolio diversification does indeed affect capital allocation.

\subsection{Robustness tests}

These results hold to a number of robustness tests that are all included in Table IX.

Internal Cash Flow. As in any study on investment, a potential criticism is that the value added growth simply captures the availability of internal cash flow rather than investment opportunities. If this is the case, then the sensitivity of capital to value added growth would not be a measure of capital allocation, but more simply a measure of financial constraints. We exploit the richness of our database that allows us to include a proxy for cash flow. For each firm each year we calculate the ratio of cash flow (as net income plus depreciation) to lagged total fixed assets. We then aggregate this measure at regional level $\left(\frac{\text { Cash Flow }_{r, t}}{\text { Total Fixed Assets } r, t-1}\right)$. Findings in Table IX show that across all models the main results remain qualitatively unaffected (although we note a small decrease in the overall economic impact for both undiversified and diversified shareholders). 
Local Finance. The idea of conducting this analysis at regional level is to be able to better identify a direct link between capital allocation and portfolio diversification of institutions headquartered in the same region. Arguably, publicly traded banks are more able than others to affect the capital allocation of firms well beyond the region where they are headquartered. Therefore, to isolate more a Local Finance effect we exclude all publicly traded banks. Results in columns (3)-(4) hold and the economic impacts are very similar to previous findings.

Bank Competition. The informational advantage banks have in a (geographical) close relation with firms within the same region may hamper the efficiency of firm capital allocation. For instance, Agarwal and Hauswald, (2010) and Degryse and Ongena (2005) show an inverse relation between the geographical distance between banks and firms and the cost of loans. Nonetheless, the presence of several banks within the same region may imply more capital available to the firms (Agarwal and Hauswald, 2010) and more competition on price. We therefore calculate the natural log of the number of banks in each region each year and include it in our model. Results in Table IX columns (5)-(10) show that the effect of portfolio diversification on capital allocation remains unaffected by bank competition.

Shareholders Type. Previous studies show that the identity of bank shareholders significantly affects the overall functioning of the economy (e.g. Morck et al., 2011). We therefore identify those instances where the bank ultimate largest shareholder is an individual (or family) and for each region each year we define the Fraction of Family-Owned Banks as the fraction of banks with an individual (family) as ultimate largest shareholder over the total number of banks in that region that year. We then augment the baseline models with this variable. Table IX columns (7)-(10) shows that even after controlling for the type of shareholders, portfolio diversification still remains an important determinant of capital allocation.

Financial Development. The development of financial markets is one of the main determinants of a better capital allocation. Without controlling for that, results in the baseline models may just pick up spurious correlation. As we argue above, our proxy of portfolio diversification may indeed be considered an indirect effect of the development of capital (in particular, stock) markets. Also, the region fixed effects should capture the local development of financial institutions. Nonetheless, we try to address this issue by including two proxies for financial development. We compute a Financial Development Index at country level as the sum of the Stock Market Development Index and the Financial Intermediary Index (similarly to Demirgüç-Kunt and Levine, 1996; and Love, 2003). ${ }^{27}$ We

\footnotetext{
${ }^{27}$ The Stock Market Development Index includes: 1) stock market capitalization ratio, which is equal to the value of listed shares as a fraction of GDP; 2) total value traded ratio, which is equal to the total shares traded on the stock market as a fraction of GDP; 3) turnover, which is the value of total shares traded in the stock market divided by the market capitalization. The Financial Intermediary Index includes: 1) liquid liabilities ratio, which is the ratio of liquid liabilities of financial intermediaries to GDP; 2) domestic credit to private sector ratio, which is the value of total domestic credit to private sector as a fraction of GDP; 3) deposits in deposit money banks ratio, which is the value of total deposits in deposit money banks as a fraction of GDP. To construct each index, we follow the two-steps procedure proposed by Demirgüç-Kunt and Levine (1996). First, for each country $c$ each year $t$ we compute the mean-adjusted value of each variable $X$ above $\left(X_{c, t}^{m}\right)$. In particular, $X_{c, t}^{m}=\frac{\left[X_{c, t}-\bar{X}_{t}\right]}{\left|\bar{X}_{t}\right|}$, where $\bar{X}_{t}$ is the average value of variable $X$ across
} 
also compute the Fraction of listed banks, calculated as the number of publicly listed banks divided by total number of banks in each region each year. When these variables are included in our analysis, results are very similar to the baseline models (columns (9)-(10)).

Finally, when we include all the bank control variables that we use in the risk-taking models, results remain unchanged.

Altogether these findings complement previous studies on the nexus between financial and economic development (e.g., Acemoglu and Zilibotti 1997; John et. al., 2008; Morck et al., 2011; Wurgler, 2000), by providing direct evidence of the effect of diversification in the economy. They suggest that the development of financial markets enhances the ability of bank shareholders to diversify their portfolio, and so their risk-taking incentives. This fosters in turn a better reallocation of resources towards riskier yet high-return investment (Levine, 2005).

\section{[INSERT TABLE IX HERE]}

\section{Conclusions}

Using a wide cross-sectional sample of both privately held and publicly listed European banks over the period 1999-2008, our paper provides novel evidence on the role played by the portfolio diversification of largest shareholders in the risk-taking decisions of banks. We first show that the average bank largest shareholder is rather diversified, having equity positions in about thirteen different companies. This complements previous evidence that shows only moderate diversification among individuals (e.g. Barber and Odean, 2000; Goetzmann and Kumar, 2008; Karhunen and Keloharju, 2001) and investors of non-financial companies (Faccio et al., 2011). We then show that banks controlled by more diversified shareholders tend to undertake more risks than those controlled by undiversified investors. This result, robust to a wide battery of different tests, is not only statistically significant but also economically important. Across all our proxies, a standard deviation increase of portfolio diversification is likely to increase the insolvency rate of the average bank by almost $4 \%$.

In the second part of our paper we provide also evidence of the influence that bank shareholders portfolio diversification exercises on the real economy. By using panel data estimations at regional level, we show that bank shareholder portfolio diversification has a positive and significant impact on capital allocation efficiency. The impact also seems economically sizeable, as we observe an increase of capital investment by almost $24 \%(9 \%)$ of its mean in regions where banks are controlled by diversified (undiversified) shareholders with average portfolio diversification. To the extent that well-functioning financial markets make it easier for investors to obtain diversified portfolios, these findings show an alternative channel through which financial development may affect the real economy.

all countries in our sample each year $t$. Second, we compute a simple average of the mean-adjusted variables included in each Index. 
Finally, results in this paper may well be relevant to the recent debate concerning the mechanisms to improve bank risk governance. Our evidence points to the fact that bank largest shareholders seem to play a non-trivial role not only in the risk-taking decisions of banks, but also in the overall development of the economy. While policy makers should protect the interests of other bank stakeholders (such as depositors and clients), they should also not sacrifice the risk-taking incentives of better diversified shareholders, because that can ultimately lead to improved capital allocation in line with the Schumpeterian view of "creative destruction". 


\section{References}

Acemoglu, D., Zilibotti, F., 1997. Was Prometheus unbound by chance? Risk, Diversification, and Growth. Journal of Political Economy 105: 709-751.

Adelman, M. A., 1969. Comment on the H Concentration Measure as a Numbers-Equivalent. Review of Economics and Statistics 511: 99-101.

Agarwal, S., Hauswald, R., 2010. Distance and Private Information in Lending. Review of Financial Studies 23: 2757-2788.

Aghion, P., Howitt, P., 1997. Endogenous Growth Theory. MIT Press.

Allen, F., Gale, D. 2004., Competition and Financial Stability. Journal of Money, Credit, and Banking 363: 453-480.

Allen, F., Fulghieri, P., Mehran, H., 2011. The Value of Bank Capital and the Structure of the Banking Industry. Review of Financial Studies 24: 971-982.

Anderson, R. C., Fraser, D. R., 2000. Corporate Control, Bank Risk Taking, and the Health of the Banking Industry. Journal of Banking \& Finance 248: 1383-1398.

Bagehot, W., 1873. Lombard Street, 1962 edition. Irwin, Homewood, IL.

Barber, B.M., Odean, T., 2000. Trading Is Hazardous to Your Wealth: The Common Stock Investment Performance of Individual Investors. Journal of Finance 552: 773-806.

Barry, T.A., Lepetit, L., Tarazi, A., 2011. Ownership structure and risk in publicly held and privately owned banks. Journal of Banking \& Finance 35: 1327-1340.

Barth, J.R., Caprio Jr., G., Levine, R., 2004. Bank Regulation and Supervision: What Works Best? Journal of Financial Intermediation 13: 205-248.

Barth, J.R., Caprio Jr., G., Levine, R., 2006. Rethinking Bank Regulation: Till Angels Govern. Cambridge University Press, Cambridge, MA.

Basel Committee on Banking Supervision, 2010a. The Basel Committee's Response to the Financial Crisis: Report to the G20. Bank for International Settlements.

Basel Committee on Banking Supervision, 2010b. Principles for Enhancing Corporate Governance. Bank for International Settlements.

Bodnaruk, A., Kendel, E., Massa, M., Simonov, A., 2008. Shareholder Diversification and the Decision to Go Public. Review of Financial Studies 21: 2769-2824.

Bound, J., Jaeger, D.A., Baker, R.M., 1995. Problems With Instrumental Variables Estimation When the Correlation Between the Instruments and the Endogenous Explanatory Variable Is Weak. Journal of the American Statistical Association 90: 443-450.

Boyd, J. H., De Nicolò, G., 2005. The Theory of Bank Risk Taking and Competition Revisited. Journal of Finance 603: 1329-1343.

Boyd, J., Graham, S., Hewitt, R., 1993. Bank Holding Company Mergers with Nonbank Financial Firms: Effects on the Risk of Failure. Journal of Banking \& Finance 171: 43-63. 
Boyd, J.H., Prescott, E.C., 1986. Financial Intermediary-Coalitions. Journal of Economic Theory 38: $211-232$.

Boyd, J.H., Runkle, D.E., 1993. Size and performance: Testing the Predictions of Banking Firms of Theory. Journal of Monetary Economics 311: 47-67.

Campbell, J.Y., Lettau, M., Malkiel, B.G., Xu, Y., 2001. Have Individual Stocks Become More Volatile? An Empirical Exploration of Idiosyncratic Risk. Journal of Finance 561: 1-43.

Caprio, G., Laeven, L., Levine, R., 2007. Governance and Bank Valuation. Journal of Financial Intermediation 16: 584-617.

Claessens, S., Djankov, S., Lang, L.H.P., 2000. The Separation of Ownership and Control in East Asian Corporations. Journal of Financial Economics 58: 81-112.

Cooper, I.A., Kaplanis, E., 1994. Home Bias in Equity Portfolios, Inflation Hedging, and International Capital Market Equilibrium. Review of Financial Studies 71: 45.

Cottarelli, C., Dell'Ariccia, G., Vladkova-Hollar, I., 2005. Early Birds, Late Risers, and Sleeping Beauties: Bank Credit Growth to the Private Sector in Central and Eastern Europe and in the Balkans. Journal of Banking \& Finance 291: 83-104.

Coval, J.D., Moskowitz, T.J., 1999. Home Bias at Home: Local Equity Preference in Domestic Portfolios. Journal of Finance 54: 2045-2074.

Dass, N., Massa, M., 2011. The Impact of a Strong Bank-Firm Relationship on the Borrowing Firm. Review of Financial Studies 24: 1204-1260.

De Nicolò, G., Loukoianova, E., 2007. Bank Ownership, Market Structure and Risk. IMF Working Paper WP/07/215.

Degryse, H., Ongena, S., 2005. Distance, Lending Relationships, and Competition. Journal of Finance 60: $231-66$.

Demirgüç-Kunt, A., Huizinga, H., 2010. Bank Activity and Funding Strategies: The Impact on Risk and Returns. Journal of Financial Economics 983: 626-650.

Demirgüç-Kunt A., Levine, R., 1996. Stock Market Development and Financial Intermediaries: Stylized Facts. World Bank Economic Review 10: 291-321.

Demsetz, H., Lehn, K., 1985. The Structure of Corporate Ownership: Causes and Consequences. Journal of Political Economy 936: 1155-1177.

Diamond, D.W., 1984. Financial Intermediation and Delegated Monitoring. Review of Economic Studies 51: 393-414.

Djankov, S., McLiesh, C., Shleifer, A., 2007. Private credit in 129 countries. Journal of Financial Economics 84: 299-329.

European Banking Federation, 2011. EU Banking Sector: Facts and Figures.

European Commission, 2007. Report on the Proportionality Principle in the European Union. 
European Commission, 2010. Corporate Governance in Financial Institutions: Lessons to be drawn from the current financial crisis, best practices.

Faccio, M., Lang, L.H.P., 2002. The ultimate ownership of Western European corporations. Journal of Financial Economics 65: 365-395.

Faccio, M., Marchica, M.-T., Mura, R., 2011. Large Shareholder Diversification and Corporate RiskTaking. Review of Financial Studies 2411: 3601-3641.

Ferreira, M., Matos, P., 2008. The colors of investors' money: The role of institutional investors around the world. Journal of Financial Economics 88: 499-533.

French, K.R., Poterba, J.M., 1991. Investor Diversification and International Equity Markets. American Economic Review 812: 222-226.

Garcia-Marco, T., Robles-Fernandez M., 2008. Risk-taking Behaviour and Ownership in the Banking Industry: The Spanish Evidence. Journal of Economics and Business 604: 332-354.

Gennaioli, N., La Porta, R., Lopez-de-Silanes, F., Shleifer, A., 2012. Human Capital and Regional Development. Quarterly Journal of Economics 128: 105-164.

Goetzmann, W. N., Kumar, A., 2008. Equity Portfolio Diversification. Review of Finance 123: 433-463.

Gorton, G., Rosen, R., 1995. Corporate Control, Portfolio Choice, and the Decline of Banking. Journal of Finance 50: 1377-1420.

Hellmann, T. F., Murdock, K.C., Stiglitz, J.E., 2000. Moral Hazard in Banking, and Prudential Liberalization, Regulation: Are Capital Requirements Enough? American Economic Review 901: $147-165$.

Houston, J.F., Lin, C., Lin, P., Ma, Y., 2010. Creditor rights, information sharing, and bank risk taking. Journal of Financial Economics 93: 485-512.

Jensen, M., Meckling, W., 1976. Theory of the Firm: Managerial Behavior, Agency Costs, and Capital Structure. Journal of Financial Economics 34: 305-360.

John, K., Litov, L., Yeung, B., 2008. Corporate Governance and Risk-Taking. Journal of Finance 63: $1679-1728$.

Karhunen, J., Keloharju, M., 2001. Share Ownership in Finland 2000. Finnish Journal of Business Economics 50: 188-226.

Keeley, M. C., 1990. Deposit Insurance, Risk, and Market Power in Banking. American Economic Review 80: 1183-1200.

Koeva, P., 2000. The Facts about Time to Build. IMF Working Paper 00/138.

Knopf, J.D., Teall, J.L., 1996. Risk-Taking Behavior in the U.S. Thrift Industry: Ownership Structure and Regulatory Changes. Journal of Banking \& Finance 20: 1329-1350.

Krainer, R.E., 1968. The Time Profile of Capital Accumulation in the Automobile Industry. Journal of Political Economy 76: 1049-1057. 
La Porta, R., Lopez-de-Silanes, F., Shleifer, A., Vishny, R.W., 1998. Law and Finance. Journal of Political Economy 106: 1113-1155.

La Porta, R., Lopez-de-Silanes, F., Shleifer, A., 2002. Government Ownership of Banks. Journal of Finance 57: 265-301.

Laeven, L., Levine, R. 2009. Bank Governance, Regulation and Risk Taking. Journal of Financial Economics 93: 259-275.

Levine, R., 1997. Financial Development and Economic Growth: Views and Agenda. Journal of Economic Literature 35: 688-726.

Levine, R., 2005. Finance And Growth: Theory And Evidence. In: Aghion P. and S.N. Durlauf (Eds), Handbook of Economic Growth Volume 1A.

Lipton, D., Sachs, J., Fischer, S., Kornai, J., 1990. Creating a Market Economy in Eastern Europe: The Case of Poland; Comments and Discussion. Brookings Papers on Economic Activity 1990: 75147.

Love, I., 2003. Financial Development and Financing Constraints: International Evidence from the Structural Investment Model. Review of Financial Studies 16: 765-791.

Lyandres, E., Marchica, M.-T., Michaely, R., Mura, R., 2013. Investment and Operating Strategies of Public and Private Firms: Theory and Evidence. Johnson School Cornell University Research Paper Series n. 18.

Mayer, T., 1960. Plant and Equipment Lead time. Journal of Business 33: 127-132.

Merton, R.C. 1992. Continuous-Time Finance. Blackwell Publishing Ltd.

Millar, J.N., 2005. Gestation Lags for Capital, Cash Flows, and Tobin's Q. Working Paper Federal Reserve Board Washington DC 24.

Morck, R., Wolfenzon, D., Yeung, B., 2005. Corporate Governance, Economic Entrenchment and Growth. Journal of Economic Literature 43: 655-720.

Morck, R., Yavuz, V. M., Yeung, B., 2011. Banking System Control, Capital Allocation, and Economy Performance. Journal of Financial Economics 100: 264-283.

Nenova, T., 2003. The Value of Corporate Voting Rights and Control: A Cross-Country Analysis. Journal of Financial Economics 68: 325-351.

Neusser, K., Kugler, V., 1998. Manufacturing Growth and Financial Development: Evidence from OECD Countries . Review of Economics and Statistics 80: 638-646.

OECD, 2010. Corporate Governance and the Financial Crisis.

Pajuste, A., 2005. Determinants and Consequences of the Unification of Dual-Class Shares. Working Paper Series No. 465.

Parrino, R., Poteshman, A.M., Weisbach, M.S., 2005. Measuring Investment Distortions When RiskAverse Managers Decide Whether to Undertake Risky Projects. Financial Management 34: 21 60. 
Petersen, M., Rajan, R., 2002. Does Distance Still Matter? The Information Revolution in Small Business Lending. Journal of Finance 57: 2533-70.

Rajan, R., Zingales, L., 1998. Financial Dependence and Growth. American Economic Review 88: 559586.

Rajan, R., Zingales, L., 2003. The Great Reversals: the Politics of Financial Development in the twentieth century. Journal of Financial Economics 69: 5-50.

Roy, A. D., 1952. Safety First and the Holding of Assets. Econometrica 203: 431-449.

Saunders, A., Strock, E., Travlos, N. G., 1990. Ownership Structure, Deregulation, and Bank Risk Taking. Journal of Finance 45: 643-654.

Schumpeter, J.A., 1912. Theorie der Wirtschaftlichen Entwicklung. Dunker \& Humblot, Leipzig. The Theory of Economic Development translated by R. Opie. Harvard University Press, Cambridge, MA, 1934.

Schumpeter, J. A., 1934. The Theory of Economic Development. An Inquiry into Profits, Capital, Credit, Interest, and the Business Cycle. Cambridge: Harvard University Press.

Schumpeter, J.A., 1942. Capitalism, Socialism, and Democracy. Harper \& Brothers, New York and London.

Sorensen, B., Wu, Y-T., Yosha, O., Zhu, Y., 2007. Home Bias and International Risk Sharing: Twin Puzzles Separated at Birth. Journal of International Money and Finance 264: 587-605.

Staiger, D., Stock, J. H., 1997. Instrumental Variables Regression with Weak Instruments. Econometrica 65: $557-86$.

Statman, M., 1987. How Many Stocks Make a Diversified Portfolio? Journal of Financial and Quantitative Analysis 223: 353-363.

Sullivan, R.J., Spong, K.R., 2007. Manager Wealth Concentration, Ownership Structure, and Risk in Commercial Banks. Journal of Financial Intermediation 162: 229-248.

Taboada, A.G., 2011. The Impact of Changes in Bank Ownership Structure on the Allocation of Capital: International Evidence. Journal of Banking \& Finance 35: 2528-2543.

Tobin, J., 1989. On the efficiency of the financial system. In: Johnson, C.(Ed.), The Market on Trial. Columbia University Press, New York, pp.125-138.

Walker Report, 2009. A Review of Corporate Governance in UK Banks and Other Financial Industry Entities. Final Recommendations.

Wooldridge, J.M., 2002. Econometric Analysis of Cross Section and Panel Data. Cambridge: MIT Press. Wurgler, J., 2000. Financial Markets and the Allocation of Capital. Journal of Financial Economics 58: $187-214$. 
Table I. Country sample distribution

\begin{tabular}{|c|c|c|c|c|}
\hline \multirow[t]{2}{*}{ Country } & \multirow[t]{2}{*}{ Total Obs } & \multicolumn{2}{|c|}{$\begin{array}{c}\text { Total Observations } \\
\%\end{array}$} & \multirow[t]{2}{*}{$\begin{array}{c}\text { Total Assets } \\
\text { (Billions USD) }\end{array}$} \\
\hline & & Public & Private & \\
\hline Albania & 13 & $0.00 \%$ & $100.00 \%$ & 2.37 \\
\hline Austria & 64 & $20.31 \%$ & $79.69 \%$ & 465.02 \\
\hline Belgium & 141 & $9.93 \%$ & $90.07 \%$ & $2,046.38$ \\
\hline Bosnia-Herzegovina & 38 & $0.00 \%$ & $100.00 \%$ & 3.35 \\
\hline Bulgaria & 86 & $11.63 \%$ & $88.37 \%$ & 12.42 \\
\hline Croatia & 98 & $39.80 \%$ & $60.20 \%$ & 42.22 \\
\hline Cyprus & 25 & $48.00 \%$ & $52.00 \%$ & 45.19 \\
\hline Czech Republic & 63 & $23.81 \%$ & $76.19 \%$ & 80.32 \\
\hline Denmark & 163 & $63.80 \%$ & $36.20 \%$ & 750.43 \\
\hline Estonia & 17 & $41.18 \%$ & $58.82 \%$ & 12.31 \\
\hline Finland & 33 & $42.42 \%$ & $57.58 \%$ & 185.71 \\
\hline France & 773 & $14.49 \%$ & $85.51 \%$ & $6,893.56$ \\
\hline Germany & 661 & $11.95 \%$ & $88.05 \%$ & $5,711.17$ \\
\hline Greece & 41 & $87.80 \%$ & $12.20 \%$ & 135.49 \\
\hline Hungary & 31 & $29.03 \%$ & $70.97 \%$ & 24.37 \\
\hline Iceland & 29 & $34.48 \%$ & $65.52 \%$ & 71.61 \\
\hline Ireland & 54 & $22.22 \%$ & $77.78 \%$ & 422.64 \\
\hline Italy & 845 & $21.78 \%$ & $78.22 \%$ & $3,440.14$ \\
\hline Latvia & 55 & $3.64 \%$ & $96.36 \%$ & 10.78 \\
\hline Lithuania & 38 & $57.89 \%$ & $42.11 \%$ & 13.03 \\
\hline Malta & 18 & $72.22 \%$ & $27.78 \%$ & 6.37 \\
\hline Republic of Moldava & 31 & $29.03 \%$ & $70.97 \%$ & 0.71 \\
\hline Netherlands & 71 & $12.68 \%$ & $87.32 \%$ & $1,073.19$ \\
\hline Norway & 159 & $74.21 \%$ & $25.79 \%$ & 289.08 \\
\hline Poland & 112 & $42.86 \%$ & $57.14 \%$ & 76.58 \\
\hline Portugal & 115 & $33.91 \%$ & $66.09 \%$ & 404.65 \\
\hline Romania & 77 & $11.69 \%$ & $88.31 \%$ & 29.06 \\
\hline Russian Federation & 193 & $8.29 \%$ & $91.71 \%$ & 116.90 \\
\hline Serbia & 21 & $0.00 \%$ & $100.00 \%$ & 3.63 \\
\hline Slovakia & 62 & $29.03 \%$ & $70.97 \%$ & 28.18 \\
\hline Slovenia & 70 & $24.29 \%$ & $75.71 \%$ & 42.70 \\
\hline Spain & 202 & $35.15 \%$ & $64.85 \%$ & $2,048.14$ \\
\hline Sweden & 73 & $50.68 \%$ & $49.32 \%$ & $1,190.51$ \\
\hline Ukraine & 60 & $3.33 \%$ & $96.67 \%$ & 13.81 \\
\hline United Kingdom & 233 & $21.89 \%$ & $78.11 \%$ & $5,023.40$ \\
\hline Yugoslavia & 3 & $0.00 \%$ & $100.00 \%$ & 1.00 \\
\hline Total/Average & 4768 & $24 \%$ & $76 \%$ & $30,716.41$ \\
\hline
\end{tabular}

This table reports the total number of European bank-year observations included in our sample. Values of Total Assets are expressed in billions of USD, inflation-adjusted using 2005 prices. Total Assets is calculated as the average over the sample period of the sum of total assets of all banks included in our sample in each country each year. 
Table II. Descriptive statistics

Panel A. Shareholder-level

\begin{tabular}{|c|c|c|c|c|c|c|}
\hline Variable & Mean & Std. Dev. & Median & Interquartile range & Min & Max \\
\hline No. of Firms & 13.748 & 32.798 & 2.000 & 8.000 & 1.000 & 262.000 \\
\hline Ln. No. of Firms & 1.301 & 1.440 & 0.693 & 2.197 & 0.000 & 5.568 \\
\hline No. of Sectors & 3.263 & 7.225 & 1.000 & 1.000 & 1.000 & 60.000 \\
\hline Ln. No of Sectors & 0.462 & 0.909 & 0.000 & 0.693 & 0.000 & 4.094 \\
\hline No. of Countries & 3.453 & 6.310 & 1.000 & 1.000 & 1.000 & 41.000 \\
\hline Ln. No of Countries & 0.574 & 0.938 & 0.000 & 0.693 & 0.000 & 3.714 \\
\hline$(1-\mathrm{HI})$ & 0.199 & 0.273 & 0.000 & 0.420 & 0.000 & 0.973 \\
\hline Diversified dummy & 0.617 & 0.486 & 1.000 & 1.000 & 0.000 & 1.000 \\
\hline \multicolumn{7}{|c|}{ No. of shareholder observations 3,010} \\
\hline \multicolumn{7}{|c|}{ Panel B. Bank-level } \\
\hline \multirow[t]{2}{*}{ Variable } & \multicolumn{3}{|c|}{ Cross section } & \multicolumn{3}{|c|}{ Panel data } \\
\hline & Mean & Std. Dev. & Median & Mean & Std. Dev. & Median \\
\hline Z-Score & 23.269 & 21.498 & 18.087 & 36.595 & 42.637 & 24.653 \\
\hline Ln. Inverse Z-score & -1.841 & 0.789 & -1.895 & -2.193 & 0.891 & -2.205 \\
\hline Ln. Vol of ROA & -5.177 & 1.022 & -5.237 & -5.111 & 1.003 & -5.173 \\
\hline Size & 14.215 & 2.123 & 14.007 & 14.290 & 2.105 & 14.096 \\
\hline CAR & 0.109 & 0.108 & 0.077 & 0.106 & 0.097 & 0.078 \\
\hline $\begin{array}{l}\text { Net Interest Marginal } \\
\text { Revenue }\end{array}$ & 0.426 & 0.237 & 0.422 & 0.440 & 0.225 & 0.452 \\
\hline Interest Activity & 2.157 & 2.410 & 1.397 & 2.098 & 2.363 & 1.362 \\
\hline Loan Loss Provisions & 0.073 & 0.081 & 0.049 & 0.072 & 0.076 & 0.053 \\
\hline Ln. No of Firms & 1.740 & 1.632 & 1.386 & 1.937 & 1.688 & 1.609 \\
\hline Ln. No of Sectors & 0.438 & 0.971 & 0.000 & 0.721 & 1.127 & 0.000 \\
\hline Ln. No of Country & 0.928 & 1.171 & 0.000 & 0.940 & 1.163 & 0.000 \\
\hline$(1-\mathrm{HI})$ & 0.244 & 0.274 & 0.132 & 0.299 & 0.302 & 0.231 \\
\hline Cash Flow Rights & 40.511 & 36.797 & 25.540 & 38.637 & 36.158 & 25.000 \\
\hline Voting Rights & 41.969 & 36.127 & 29.735 & 40.099 & 35.587 & 27.680 \\
\hline Fraction of Wealth & 0.575 & 0.450 & 0.854 & 0.539 & 0.453 & 0.609 \\
\hline \multicolumn{4}{|c|}{ No. of shareholder 817} & \multicolumn{3}{|c|}{ No. of shareholder obs 3,010} \\
\hline
\end{tabular}


Panel C. Region-level

\begin{tabular}{lcccccc}
\hline \multicolumn{1}{c}{ Variable } & Mean & Std. Dev. & Median & $\begin{array}{c}\text { Interquartile } \\
\text { range }\end{array}$ & Min & Max \\
\hline Capital Investment & 0.372 & 0.182 & 0.365 & 0.264 & -0.214 & 1.605 \\
Value Added Growth & 0.123 & 0.129 & 0.144 & 0.195 & -0.357 & 0.685 \\
Cash Flow & 0.831 & 0.467 & 0.760 & 0.570 & -0.400 & 3.051 \\
Ln. No of Firms & 2.804 & 1.271 & 3.018 & 1.685 & 0.000 & 5.568 \\
$(1-H I)$ & 0.359 & 0.223 & 0.348 & 0.286 & 0.000 & 0.953 \\
Bank Competition & 1.365 & 1.120 & 1.386 & 1.386 & 0.000 & 5.088 \\
Fraction of Family-Owned Banks & 0.118 & 0.213 & 0.000 & 0.167 & 0.000 & 1.000 \\
Financial Development Index & 0.639 & 0.991 & 0.453 & 1.003 & -1.587 & 3.864 \\
Fraction of Listed Banks & 0.241 & 0.323 & 0.102 & 0.364 & 0.000 & 1.000 \\
\hline
\end{tabular}

No. of region observations 1,038

This table reports summary statistics at shareholder- (Panel A), bank- (Panel B) and region-(Panel C) level, of the main dependent and independent variables. Ln No. of Firms is the natural logarithm of the total number of firms owned directly or indirectly by each bank largest shareholder. Ln No. of Sector is the natural logarithm of the total number of different 3-dgt US SIC sectors in which the largest shareholder invests (No. of Sectors); $L n$ No. of Country is the natural logarithm of the total number of countries where the largest shareholder invests (No. of Countries). The Herfindahl Index measures the ownership concentration of shareholders, calculated as the squared sum of each weighted investment in the shareholder's portfolio, relative to the shareholder's total wealth. Diversified dummy is a dummy equal to one if the ultimate largest shareholder's portfolio holds stocks from at least two companies, zero otherwise. The Inverse Z-score is the ratio of the volatility of $R O A\left(\sigma_{i, R O A}\right)$ to the sum of average return on asset ( $\operatorname{avgROA})$ and average capital asset ratio (avgCAR). At cross-section level each component of the Inverse Z-score is calculated over the entire time series of each bank between 1999 and 2008, requiring at least five year observations of $R O A$. ROA is defined as the ratio of the gross pre-tax profit (including loan loss provisions) to total assets. The volatility of ROA is the standard deviation of ROA; avgROA is the average of $R O A$; $\operatorname{avgCAR}$ is the average ratio of equity to total assets. At panel level each component is calculated over five years overlapping periods. Size is the natural logarithm of total assets; CAR is as the ratio of equity to total assets; Net Interest Marginal Revenue is the ratio of the difference between interest income and interest expenses to the interest income; Interest Activity is the ratio of interest income to total operating income; Loan Loss Provisions is the ratio of Loan Loss Provision (LLP) reported in banks' income statements to Interest Income. Cash Flow Rights and Voting Rights represent the cash flow rights and voting rights respectively held by the ultimate largest shareholder. For instance, if shareholder A owns a fraction $\mathrm{x}$ of company B, which owns in turn a fraction y of bank $\mathrm{C}$, shareholder $\mathrm{A}$ then is identified as the ultimate shareholder of bank C. We calculate the Cash Flow Rights of each ultimate shareholder as the product between links along the chain; and the Voting Rights as the weakest link along the chain. In the small example above, Cash Flow Rights of shareholder A are equal to $C F_{A C}=x \times y$, while the Voting Rights are equal to $V R_{A C}=$ $\min [x, y]$; Fraction of Wealth represents the fraction of wealth of each shareholder invested in each company held in the shareholder's portfolio. It is equal to $\frac{B E_{C} \times C F_{A C}}{T W_{A}}$, where $\left(B E_{C} \times C F_{A C}\right)$ is defined as the dollar value investment of shareholder $A$ in company $C$, which is the product between the book value of equity of company $c$ and the fraction of Cash Flow Rights of shareholder $A$ in company $C ; T W_{A}$ is the total value of the portfolio of shareholder A, proxy of the shareholder's Total Wealth. All variables in Panel C are computed at regional level. Capital Investment represents the capital expenditure in region $r$ at year $t$, relative to the capital stock. Value Added Growth is the natural log of the change in value added between year $t$ and year $t-1$; value added in constant US dollars (year 2000 prices), is defined as earnings before interest and taxes plus the cost of employees. Cash Flow is equal to the ratio of cash flow (as net income plus depreciation) to lagged total fixed assets in region $r$ at year $t$. Portfolio diversification proxies are calculated across all banks in each region $r$ each year. Bank Competition is equal to the natural log of the number of banks in each region each year. Fraction of Family-Owned Banks is the fraction of banks with an individual (family) as ultimate largest shareholder over the total number of banks in each region each year. Financial Development Index is calculated at country level as the sum of the Stock Market Development Index and the Financial Intermediary Index, similar to DemirgüçKunt and Levine (1996) and Love (2003). Fraction of listed banks is calculated as the number of publicly listed banks divided by the total number of banks in each region $r$ each year. 
Table III. Cross-sectional regressions

\begin{tabular}{|c|c|c|c|c|}
\hline Inverse Z-score & $\begin{array}{c}\text { Ln } \\
\text { No. of Firms }\end{array}$ & $\begin{array}{c}\text { Ln } \\
\text { No. of Sectors }\end{array}$ & $\begin{array}{c}\text { Ln } \\
\text { No. of Countries }\end{array}$ & $(1-H I)$ \\
\hline \multirow[t]{3}{*}{ Portfolio Diversification } & $0.0371 * *$ & $0.1029 * * *$ & $0.0548 * *$ & $0.2220 * *$ \\
\hline & {$[0.0251]$} & {$[0.0000]$} & {$[0.0130]$} & {$[0.0131]$} \\
\hline & $3.29 \%$ & $5.42 \%$ & $3.49 \%$ & $3.30 \%$ \\
\hline \multirow[t]{2}{*}{ Cash Flow Rights } & 0.001 & $0.0012 *$ & 0.001 & 0.0007 \\
\hline & {$[0.1464]$} & {$[0.0780]$} & {$[0.1497]$} & {$[0.2937]$} \\
\hline \multirow[t]{2}{*}{ Size } & -0.0009 & -0.0027 & -0.0011 & 0.0015 \\
\hline & {$[0.9542]$} & {$[0.8506]$} & {$[0.9437]$} & {$[0.9155]$} \\
\hline \multirow[t]{2}{*}{ CAR } & $-0.5341 * *$ & $-0.4856^{* *}$ & $-0.5644^{* *}$ & $-0.5075^{* *}$ \\
\hline & {$[0.0225]$} & {$[0.0372]$} & {$[0.0163]$} & {$[0.0293]$} \\
\hline \multirow[t]{2}{*}{ Net Interest Marginal Revenue } & $-0.6161 * * *$ & $-0.6168 * * *$ & $-0.6080 * * *$ & $-0.6208 * * *$ \\
\hline & {$[0.0000]$} & {$[0.0000]$} & {$[0.0000]$} & {$[0.0000]$} \\
\hline \multirow[t]{2}{*}{ Interest Activity } & $-0.0353 * *$ & $-0.0335 * *$ & $-0.0357 * *$ & $-0.0360 * *$ \\
\hline & {$[0.0157]$} & {$[0.0212]$} & {$[0.0142]$} & {$[0.0145]$} \\
\hline \multirow[t]{2}{*}{ Loan Loss Provision } & $0.8634 * * *$ & $0.8712 * * *$ & $0.8686^{* * *}$ & $0.8552 * * *$ \\
\hline & {$[0.0067]$} & {$[0.0059]$} & {$[0.0063]$} & {$[0.0071]$} \\
\hline \multirow[t]{2}{*}{ Private dummy } & -0.0751 & -0.0792 & -0.075 & -0.0555 \\
\hline & {$[0.2279]$} & [0.1998] & {$[0.2271]$} & {$[0.3683]$} \\
\hline \multirow[t]{2}{*}{ Intercept } & $-1.6219 * * *$ & $-1.6423 * * *$ & $-1.5917 * * *$ & $-1.6583 * * *$ \\
\hline & {$[0.0000]$} & {$[0.0000]$} & {$[0.0000]$} & {$[0.0000]$} \\
\hline Country fixed effects & Yes & Yes & Yes & Yes \\
\hline Year fixed effects & Yes & Yes & Yes & Yes \\
\hline Adjusted R-squared & 0.1294 & 0.1380 & 0.1304 & 0.1301 \\
\hline No. of observations & 1,184 & 1,184 & 1,184 & 1,184 \\
\hline
\end{tabular}

This table reports cross-sectional regression results where the dependent variable is the Ln. Inverse Z-score. The Inverse Z-score is the ratio of the volatility of $R O A\left(\sigma_{i, R O A}\right)$ to the sum of average return on assets (avgROA) and average capital asset ratio (avgCAR). Each component of the Inverse Z-score is calculated over the entire time series of each bank between 1999 and 2008, requiring at least five year observations of $R O A$. ROA is defined as the ratio of the gross pre-tax profit (including loan loss provisions) to total assets. The volatility of ROA is the standard deviation of ROA; avgROA is the average of ROA; avgCAR is the average ratio of equity to total assets. All independent variables are taken at the beginning of the period over which the Inverse Z-score is calculated. Ln No. of Firms is the main portfolio diversification variable, and is the natural logarithm of the total number of firms owned directly or indirectly by each bank's largest shareholder. Ln No. of Sector is the natural logarithm of the total number of different 3-dgt US SIC sectors in which the largest shareholder invests; Ln No. of Country is the natural logarithm of the total number of countries where the largest shareholder invests. The Herfindahl Index measures the ownership concentration of shareholders, calculated as the squared sum of the weight of each investment in the shareholder's portfolio, relative to the shareholder's total wealth. Cash Flow Rights represents the cash flow rights held by the ultimate largest shareholder. Size is the natural logarithm of total assets; Net Interest Marginal Revenue is the ratio of the difference between interest income and interest expenses to the interest income; Interest Activity is the ratio of interest income to total operating income; Loan Loss Provisions is the ratio of Loan Loss Provision (LLP) reported in banks' income statements to Interest Income. Private dummy is a binary variable equal to 1 if the bank is privately held, 0 otherwise. All regressions include country and year fixed effects, and standard errors are correct for heteroskedasticity. The economic impact of each portfolio diversification proxy is reported below the corresponding p-value in bold. The economic impact is calculated as the percentage change of the average bank risk-taking in response to a standard deviation increase of the portfolio diversification variable. P-values are reported in brackets. *,**, and *** report the statistical significance at the $10 \%, 5 \%$, and $1 \%$ levels, respectively. 
Table IV. Panel data regressions

\begin{tabular}{lcccc}
\hline \hline \multicolumn{1}{c}{ Inverse Z-score } & Ln & Ln & Ln & $(1-H I)$ \\
\hline Portfolio Diversification & $0.0409^{* *}$ & $0.0485^{* *}$ & $0.0671^{* * *}$ & $0.1408^{*}$ \\
& {$[0.0137]$} & {$[0.0448]$} & {$[0.0053]$} & {$[0.0912]$} \\
Cash Flow Rights & $3.15 \%$ & $2.49 \%$ & $3.56 \%$ & $1.94 \%$ \\
Size & 0.0009 & 0.0008 & 0.0009 & 0.0005 \\
& {$[0.2634]$} & {$[0.2872]$} & {$[0.2414]$} & {$[0.5123]$} \\
CAR & $-0.0301^{*}$ & $-0.0295^{*}$ & $-0.0318^{*}$ & -0.0271 \\
& {$[0.0744]$} & {$[0.0789]$} & {$[0.0601]$} & {$[0.1072]$} \\
Net Interest Marginal Revenue & $-0.6572^{* *}$ & $-0.6466^{* *}$ & $-0.6795^{* *}$ & $-0.6443^{* *}$ \\
& {$[0.0231]$} & {$[0.0253]$} & {$[0.0189]$} & {$[0.0262]$} \\
Interest Activity & $-0.8127^{* * *}$ & $-0.8171^{* * *}$ & $-0.8110^{* * *}$ & $-0.8110^{* * *}$ \\
& {$[0.0000]$} & {$[0.0000]$} & {$[0.0000]$} & {$[0.0000]$} \\
Loan Loss Provision & $-0.0234^{*}$ & $-0.0235^{*}$ & $-0.0240^{*}$ & $-0.0243^{*}$ \\
Private dummy & {$[0.0756]$} & {$[0.0744]$} & {$[0.0688]$} & {$[0.0659]$} \\
& $0.7675^{* *}$ & $0.7707^{* *}$ & $0.7919^{* *}$ & $0.7639^{* *}$ \\
Intercept & {$[0.0186]$} & {$[0.0181]$} & {$[0.0153]$} & {$[0.0193]$} \\
& -0.008 & -0.0129 & -0.0036 & -0.0223 \\
Shareholder fixed effects & {$[0.9051]$} & {$[0.8469]$} & {$[0.9567]$} & {$[0.7377]$} \\
Country fixed effects & -0.1558 & -0.1786 & -0.1257 & $-1.3292^{* * *}$ \\
Year fixed effects & {$[0.7367]$} & {$[0.6968]$} & {$[0.7870]$} & {$[0.0010]$} \\
Adjusted R-squared & Yes & Yes & Yes & Yes \\
No. of observations & Yes & Yes & Yes & Yes \\
\hline \hline
\end{tabular}

This table reports panel data results where the dependent variable is the Ln. Inverse Z-score. The Inverse ZScore is the ratio of volatility of ROA $\left(\sigma_{i, R O A}\right)$ to the sum of average return on assets $(\operatorname{avgROA})$ and average capital asset ratio ( $\operatorname{vg} C A R)$. Each component of the inverse Z-score is calculated over five consecutive year overlapping periods, that is, 2000-2004, 2001-2005, 2002-2006, 2003-2007 and 2004-2008. ROA is defined as the ratio of the gross pre-tax profit (including loan loss provisions) to total assets. The volatility of $R O A$ is the standard deviation of ROA; avgROA is the average of $R O A$; avgCAR is the average ratio of equity to total assets. All independent variables are taken at the beginning of the period over which the inverse Zscore is calculated. Ln No. of Firms is the main portfolio diversification variable, and is the natural logarithm of the total number of firms owned directly or indirectly by each bank's largest shareholder. Ln No. of Sector is the natural logarithm of the total number of different 3-dgt US SIC sectors in which the largest shareholder invests; Ln No. of Country is the natural logarithm of the total number of countries where the largest shareholder invests. The Herfindahl Index measures the ownership concentration of shareholders, calculated as the squared sum of the weight of each investment in the shareholder's portfolio, relative to the shareholder's total wealth. Cash Flow Rights represents the cash flow rights held by the ultimate largest shareholder. Size is the natural logarithm of total assets; Net Interest Marginal Revenue is the ratio of the difference between interest income and interest expenses to the interest income; Interest Activity is the ratio of interest income to total operating income; Loan Loss Provisions is the ratio of Loan Loss Provision (LLP) reported in banks' income statements to Interest Income. Private dummy is a binary variable equal to 1 if the bank is privately held, 0 otherwise. All regressions include shareholder, country and year fixed effects, and standard errors are correct for heteroskedasticity. The economic impact of each portfolio diversification proxy is reported below the corresponding p-value in bold. The economic impact is calculated as the percentage change of the average bank risk-taking in response to a standard deviation increase of the portfolio diversification variable. P-values are reported in brackets. *,**, and *** report the statistical significance at the $10 \%, 5 \%$, and $1 \%$ levels, respectively. 
Table V. Instrumental variable regressions

Panel A. Whole sample

\begin{tabular}{|c|c|c|c|c|}
\hline \multicolumn{5}{|c|}{ Second-Stage regressions } \\
\hline Inverse Z-score & $\begin{array}{c}\text { Ln } \\
\text { No. of Firms }\end{array}$ & $\begin{array}{c}\operatorname{Ln} \\
\text { No. of Sectors }\end{array}$ & $\begin{array}{c}\text { Ln } \\
\text { No. of Countries }\end{array}$ & $(1-H I)$ \\
\hline \multirow[t]{3}{*}{ Portfolio Diversification } & $0.130^{*}$ & $0.277 * * *$ & $0.185^{* *}$ & $0.691^{*}$ \\
\hline & {$[0.067]$} & {$[0.007]$} & {$[0.036]$} & {$[0.084]$} \\
\hline & $11.52 \%$ & $14.61 \%$ & $11.76 \%$ & $10.27 \%$ \\
\hline \multirow[t]{2}{*}{ Cash Flow Rights } & $0.002 *$ & $0.002^{* *}$ & $0.002 * *$ & 0.001 \\
\hline & {$[0.063]$} & {$[0.022]$} & [0.049] & {$[0.160]$} \\
\hline \multirow[t]{2}{*}{ Size } & -0.013 & -0.014 & -0.013 & -0.004 \\
\hline & {$[0.579]$} & [0.493] & {$[0.559]$} & {$[0.856]$} \\
\hline \multirow{2}{*}{ CAR } & -0.364 & -0.188 & -0.499 & -0.215 \\
\hline & {$[0.224]$} & {$[0.523]$} & {$[0.106]$} & {$[0.483]$} \\
\hline \multirow[t]{2}{*}{ Net Interest Marginal Revenue } & $-0.719 * * *$ & $-0.746^{* * *}$ & $-0.670 * * *$ & $-0.773 * * *$ \\
\hline & {$[0.000]$} & {$[0.000]$} & {$[0.000]$} & {$[0.000]$} \\
\hline \multirow[t]{2}{*}{ Interest Activity } & $-0.042 * *$ & $-0.038 * *$ & $-0.043 * * *$ & $-0.042 * *$ \\
\hline & {$[0.011]$} & {$[0.020]$} & {$[0.008]$} & {$[0.024]$} \\
\hline \multirow[t]{2}{*}{ Loan Loss Provision } & 0.2 & 0.299 & 0.229 & 0.042 \\
\hline & {$[0.665]$} & {$[0.511]$} & {$[0.617]$} & {$[0.929]$} \\
\hline \multirow[t]{2}{*}{ Private dummy } & $-0.162 *$ & $-0.141 *$ & $-0.158 * *$ & -0.069 \\
\hline & {$[0.053]$} & {$[0.070]$} & [0.049] & {$[0.363]$} \\
\hline Country fixed effects & Yes & Yes & Yes & Yes \\
\hline Year fixed effects & Yes & Yes & Yes & Yes \\
\hline No. of observations & 866 & 866 & 866 & 811 \\
\hline \multicolumn{5}{|c|}{ First-Stage regressions } \\
\hline Portfolio Diversification & $\begin{array}{c}\text { Ln } \\
\text { No. of Firms }\end{array}$ & $\begin{array}{c}\operatorname{Ln} \\
\text { No. of Sectors }\end{array}$ & $\begin{array}{c}\text { Ln } \\
\text { No. of Countries }\end{array}$ & $(1-H I)$ \\
\hline \multirow{2}{*}{$\begin{array}{l}\text { Average Portfolio Diversification } \\
\text { (same region/year) }\end{array}$} & $0.777 * * *$ & $0.976 * * *$ & $0.796 * * *$ & $0.863 * * *$ \\
\hline & {$[0.000]$} & {$[0.000]$} & {$[0.000]$} & {$[0.000]$} \\
\hline $\begin{array}{l}\text { Partial R-squared of excluded } \\
\text { instruments }\end{array}$ & 0.067 & 0.086 & 0.072 & 0.066 \\
\hline F-test of excluded instruments & 73.797 & 51.422 & 92.546 & 65.390 \\
\hline
\end{tabular}


Table V. Instrumental variable regressions (cont'd)

Panel B. Non-UK sample

\begin{tabular}{|c|c|c|c|c|}
\hline \multicolumn{5}{|c|}{ Second-Stage regressions } \\
\hline Inverse Z-score & $\begin{array}{c}\text { Ln } \\
\text { No. of Firms }\end{array}$ & $\begin{array}{c}\operatorname{Ln} \\
\text { No. of Sectors }\end{array}$ & $\begin{array}{c}\text { Ln } \\
\text { No. of Countries }\end{array}$ & $(1-H I)$ \\
\hline \multirow[t]{2}{*}{ Portfolio Diversification } & $0.492 * *$ & $0.751 * * *$ & $0.552 * * *$ & $5.59^{*}$ \\
\hline & {$[0.010]$} & {$[0.009]$} & {$[0.004]$} & {$[0.100]$} \\
\hline \multirow{2}{*}{ Cash Flow Rights } & $0.008 * * *$ & $0.006 * * *$ & $0.006 * * *$ & 0.005 \\
\hline & [0.009] & {$[0.008]$} & {$[0.005]$} & {$[0.121]$} \\
\hline \multirow[t]{2}{*}{ Size } & $-0.131 * *$ & $-0.092 * *$ & $-0.106 * *$ & -0.201 \\
\hline & {$[0.018]$} & {$[0.024]$} & {$[0.014]$} & {$[0.121]$} \\
\hline \multirow[t]{2}{*}{ CAR } & -0.616 & -0.068 & $-1.009 * *$ & 0.323 \\
\hline & {$[0.218]$} & {$[0.875]$} & {$[0.037]$} & {$[0.728]$} \\
\hline \multirow[t]{2}{*}{ Net Interest Marginal Revenue } & $-0.795 * * *$ & $-0.795 * * *$ & $-0.674 * * *$ & $-1.047 * * *$ \\
\hline & {$[0.000]$} & {$[0.000]$} & {$[0.001]$} & {$[0.004]$} \\
\hline \multirow[t]{2}{*}{ Interest Activity } & -0.026 & -0.016 & -0.032 & -0.017 \\
\hline & {$[0.271]$} & {$[0.488]$} & {$[0.125]$} & {$[0.652]$} \\
\hline \multirow[t]{2}{*}{ Loan Loss Provision } & -0.675 & 0.036 & -0.25 & -0.7 \\
\hline & {$[0.415]$} & {$[0.956]$} & {$[0.715]$} & {$[0.587]$} \\
\hline \multirow[t]{2}{*}{ Private dummy } & $-0.322 * *$ & -0.198 & $-0.260 * *$ & -0.109 \\
\hline & {$[0.039]$} & {$[0.124]$} & {$[0.038]$} & {$[0.563]$} \\
\hline Country fixed effects & Yes & Yes & Yes & Yes \\
\hline Year fixed effects & Yes & Yes & Yes & Yes \\
\hline No. of observations & 696 & 696 & 696 & 696 \\
\hline \multicolumn{5}{|c|}{ First-Stage regressions } \\
\hline Portfolio Diversification & $\begin{array}{c}\text { Ln } \\
\text { No. of Firms }\end{array}$ & $\begin{array}{c}\text { Ln } \\
\text { No. of Sectors }\end{array}$ & $\begin{array}{c}\text { Ln } \\
\text { No. of Countries }\end{array}$ & $(1-H I)$ \\
\hline \multirow{2}{*}{$\begin{array}{l}\text { Fraction of Diversified Investors } \\
\text { (same geographic distance) }\end{array}$} & $1.463 * * *$ & $0.958 * * *$ & $1.305 * * *$ & $0.129 *$ \\
\hline & {$[0.001]$} & {$[0.000]$} & {$[0.000]$} & {$[0.082]$} \\
\hline $\begin{array}{l}\text { Partial R-squared of excluded } \\
\text { instruments }\end{array}$ & 0.018 & 0.02 & 0.026 & 0.005 \\
\hline F-test of excluded instruments & 12.189 & 12.920 & 17.978 & 3.026 \\
\hline
\end{tabular}

This table reports instrumental variable cross-sectional regression results. In the second stage regressions, the dependent variable is the Ln. Inverse Z-score. In Panel A, we use Average Portfolio Diversification (same region/year), defined as the average portfolio diversification of large shareholders across all other banks in the same region and year as the bank in question, as instrument for the corresponding portfolio diversification measure. In Panel B, which is run for the sub-set of non-UK banks, the IV is the Fraction of Diversified Investors (same geographic distance) in the UK, defined as the fraction of UK banks with the same geographic distance to the stock markets, whose largest shareholder holds a diversified portfolio. The Inverse Z-score is the ratio of the volatility of ROA $\left(\sigma_{i, R O A}\right)$ to the sum of average return on assets (avgROA) and average capital asset ratio $(\operatorname{avgCAR})$. Each component of the Inverse Z-score is calculated over the entire time series of each bank between 1999 and 2008, requiring at least five year observations of ROA. ROA is defined as the ratio of the gross pre-tax profit (including loan loss provisions) to total assets. The volatility of $R O A$ is the standard deviation of $R O A$; avgROA is the average of $R O A$; avgCAR is the average ratio of equity to total assets. All independent variables are taken at the beginning of the period over which the Inverse Zscore is calculated. Ln No. of Firms is the main portfolio diversification variable, and is the natural logarithm of the total number of firms owned directly or indirectly by each bank's largest shareholder. Ln No. of Sector 
is the natural logarithm of the total number of different 3-dgt US SIC sectors in which the largest shareholder invests; Ln No. of Country is the natural logarithm of the total number of countries where the largest shareholder invests. The Herfindahl Index measures the ownership concentration of shareholders, calculated as the squared sum of the weight of each investment in the shareholder's portfolio, relative to the shareholder's total wealth. Cash Flow Rights represents the cash flow rights held by the ultimate largest shareholder. Size is the natural logarithm of total assets; Net Interest Marginal Revenue is the ratio of the difference between interest income and interest expenses to the interest income; Interest Activity is the ratio of interest income to total operating income; Loan Loss Provisions is the ratio of Loan Loss Provision (LLP) reported in banks' income statements to Interest Income. Private dummy is a binary variable equal to 1 if the bank is privately held, 0 otherwise. All regressions include country and year fixed effects, and standard errors are correct for heteroskedasticity. P-values are reported in brackets. *,**, and *** report the statistical significance at the $10 \%, 5 \%$, and $1 \%$ levels, respectively. 
Table VI. Credit rating downgrades

\begin{tabular}{lcccc}
\hline \hline \multicolumn{1}{c}{ Variable } & $\begin{array}{c}\text { Obs } \\
\text { (Bank-years) }\end{array}$ & Mean & $\begin{array}{c}\Delta \text { Mean } \\
\text { (After-Before) }\end{array}$ & $\begin{array}{c}\text { P-Value } \\
(\Delta \text { Mean=0) }\end{array}$ \\
\hline $\begin{array}{lccc}\text { Inverse Z-score (pre-downgrade) } \\
\text { Inverse Z-score (post-downgrade) }\end{array}$ & 57 & 0.110 & & \\
& & 0.193 & 0.083 & 0.002 \\
No of Firms (pre-downgrade) & 57 & 25.085 & & \\
No of Firms (post-downgrade) & & 25.359 & 0.274 & 0.981 \\
\hline \hline
\end{tabular}

This table reports tests for differences in the mean of changes in risk-taking and portfolio diversification before and after a downgrade event. A downgrade event is identified when a bank in a certain year experiences a negative change in its credit rating of at least one notch from the previous available rating. Risk-taking is measured as the Inverse Z-score, that is, the ratio of volatility of $R O A\left(\sigma_{i, R O A}\right)$ to the sum of average return on assets $(\operatorname{avg} R O A)$ and average capital asset ratio $(\operatorname{avg} C A R)$, requiring at least five consecutive observations of ROA. Portfolio diversification is measured as the No. of Firms, the main proxy for portfolio diversification, equal to the total number of firms owned directly or indirectly by each bank largest shareholder. 
Table VII. Further robustness tests

\begin{tabular}{|c|c|c|c|c|c|c|c|c|c|c|}
\hline & $\sigma_{i, R O A}$ & Survival & $\begin{array}{c}\text { Diversification } \\
\text { Dummy }\end{array}$ & $\begin{array}{c}\text { Dual class } \\
\text { shares }\end{array}$ & $\begin{array}{l}\text { Mutual } \\
\text { Funds }\end{array}$ & $\begin{array}{c}\text { Managerial } \\
\text { Ownership }\end{array}$ & $\begin{array}{c}>=10 \% \\
\text { Voting } \\
\text { Rights }\end{array}$ & Bank Type & $\begin{array}{l}\text { Institutional } \\
\text { Settings }\end{array}$ & $\begin{array}{l}\text { No Eastern } \\
\text { Europe }\end{array}$ \\
\hline \multirow[t]{3}{*}{ Ln No. of Firms } & $0.0342 *$ & $-0.1992 * * *$ & $0.0905^{*}$ & $0.0459 * *$ & $0.0402 * *$ & $0.0381 * *$ & $0.0429 * *$ & $0.0344 * *$ & $0.0384 * *$ & $0.0544 * * *$ \\
\hline & {$[0.0572]$} & {$[0.0000]$} & {$[0.0871]$} & {$[0.0145]$} & {$[0.0167]$} & {$[0.0221]$} & {$[0.0357]$} & [0.0393] & [0.0239] & {$[0.0037]$} \\
\hline & $1.08 \%$ & $6.28 \%$ & $4.92 \%$ & $4.07 \%$ & $3.56 \%$ & $3.37 \%$ & $3.80 \%$ & $3.05 \%$ & $3.4 \%$ & $4.83 \%$ \\
\hline \multirow{2}{*}{ Cash Flow Rights } & $0.0342 *$ & $-0.0061 * * *$ & 0.0006 & 0.0012 & 0.001 & 0.001 & 0.0013 & 0.0011 & $0.0384 * *$ & 0.001 \\
\hline & {$[0.0572]$} & {$[0.0023]$} & {$[0.3428]$} & {$[0.1515]$} & {$[0.1707]$} & {$[0.1457]$} & [0.1398] & {$[0.1322]$} & {$[0.0239]$} & [0.1947] \\
\hline \multirow[t]{2}{*}{ Size } & 0.0013 & $0.1923 * * *$ & 0.0039 & 0.0136 & -0.0058 & -0.0005 & -0.0227 & 0.0029 & 0.0012 & 0.001 \\
\hline & {$[0.1120]$} & {$[0.0000]$} & {$[0.7914]$} & {$[0.4192]$} & {$[0.7038]$} & {$[0.9756]$} & {$[0.2142]$} & {$[0.8486]$} & {$[0.1058]$} & [0.9513] \\
\hline \multirow{2}{*}{ CAR } & $-0.0684 * * *$ & $-1.1050 *$ & $-0.5051 * *$ & $-0.5183 * *$ & $-0.5527 * *$ & $-0.5223 * *$ & $-0.7130 * * *$ & $-0.4961 * *$ & -0.0029 & -0.3596 \\
\hline & {$[0.0001]$} & {$[0.0525]$} & {$[0.0304]$} & {$[0.0413]$} & {$[0.0208]$} & {$[0.0262]$} & {$[0.0053]$} & {$[0.0353]$} & {$[0.8495]$} & {$[0.2044]$} \\
\hline \multirow{2}{*}{ Net Interest Marginal Revenue } & $2.5709 * * *$ & $0.7664 * *$ & $-0.6218 * * *$ & $-0.4133 * * *$ & $-0.6390 * * *$ & $-0.6165 * * *$ & $-0.6359 * * *$ & $-0.6320 * * *$ & $-0.5640 * *$ & $-0.6946 * * *$ \\
\hline & {$[0.0000]$} & {$[0.0290]$} & {$[0.0000]$} & {$[0.0084]$} & {$[0.0000]$} & {$[0.0000]$} & {$[0.0001]$} & {$[0.0000]$} & {$[0.0168]$} & {$[0.0000]$} \\
\hline Interest Activity & -0.2631 & -0.0261 & $-0.0354 * *$ & $-0.0374 * *$ & $-0.0326^{* *}$ & $-0.0353 * *$ & $-0.0290^{*}$ & $-0.0330 * *$ & $-0.6302 * * *$ & $-0.0395 * * *$ \\
\hline \multirow{2}{*}{ Loan Loss Provision } & $-0.0854 * * *$ & $2.4119 * *$ & $0.8668 * * *$ & $0.8604 * * *$ & $0.9555 * * *$ & $0.8681 * * *$ & $0.8759 * *$ & $0.8140 * *$ & $-0.0387 * *$ & $0.8777^{*}$ \\
\hline & {$[0.0000]$} & {$[0.0182]$} & {$[0.0064]$} & [0.0094] & {$[0.0025]$} & {$[0.0065]$} & {$[0.0174]$} & {$[0.0110]$} & {$[0.0101]$} & {$[0.0643]$} \\
\hline \multirow{2}{*}{ Private dummy } & $-1.2465^{* * *}$ & $-0.4219 * *$ & -0.0623 & -0.075 & -0.0645 & -0.0767 & 0.0807 & -0.074 & $0.8617 * * *$ & -0.0847 \\
\hline & {$[0.0004]$} & {$[0.0283]$} & {$[0.3146]$} & [0.3051] & {$[0.3071]$} & {$[0.2197]$} & {$[0.3207]$} & {$[0.2384]$} & {$[0.0073]$} & {$[0.2420]$} \\
\hline \multirow[t]{2}{*}{ Managerial Ownership } & & & & & & $0.0054^{*}$ & & & & \\
\hline & & & & & & {$[0.0814]$} & & & & \\
\hline \multirow{2}{*}{ Bank Type } & & & & & & & & $0.1170 * *$ & & \\
\hline & & & & & & & & {$[0.0320]$} & & \\
\hline \multirow[t]{2}{*}{ Capital Stringency Index } & & & & & & & & & $-0.1129 * * *$ & \\
\hline & & & & & & & & & {$[0.0004]$} & \\
\hline \multirow[t]{2}{*}{ Restrict Index } & & & & & & & & & $0.1002 * * *$ & \\
\hline & & & & & & & & & {$[0.0049]$} & \\
\hline Creditor Rights Index & & & & & & & & & -0.0518 & \\
\hline
\end{tabular}




Yes

Yes

\section{Yes
Yes}

Year fixed effects

Adjusted R-squared

Yes

Yes

0.015

Yes

0.127

1,698

1,184

Yes
Yes

0.118

924

Yes

Yes

0.135

1,123

Yes

Yes

0.128

1,181
[0.0002]

$-0.3178$

[0.5900]
$-1.7116^{* * * *}$

[0.0000]

This table reports cross-sectional regression results of several robustness tests. In column (1) the dependent variable is Ln. volatility of ROA ( $\left.\sigma_{i, R O A}\right)$ which is the standard deviation of ROA calculated over the entire time series of each bank between 1999 and 2008, requiring at least five year observations. $R O A$ is defined as the ratio of the gross pre-tax profit (including loan loss provisions) to total assets. In column (2) Survival is a binary variable equal to 1 if a bank entering our sample before 2004 survives for at least five years, and 0 otherwise. In columns (3)-(5) the dependent variable is the Ln. Inverse Z-score, which is the ratio of the volatility of $R O A\left(\sigma_{i, R O A}\right)$ to the sum of average return on assets $(\operatorname{avgROA})$ and average capital asset ratio $(\operatorname{avg} C A R)$. Each component of the Inverse Z-score is calculated over the entire time series of each bank between 1999 and 2008, requiring at least five year observations of ROA. All independent variables are taken at the beginning of the period over which the dependent variables are calculated. Ln No. of Firms is the main portfolio diversification variable, calculated as the natural logarithm of the total number of firms owned directly or indirectly by each bank largest shareholder. Cash Flow Rights represents the cash flow rights held by the ultimate largest shareholder. Size is the natural logarithm of total assets; Net Interest Marginal Revenue is the ratio of the difference between interest income and interest expenses to the interest income; Interest Activity is the ratio of interest income to total operating income; Loan Loss Provisions is the ratio of Loan Loss Provision reported in banks' income statements to Interest Income. Private dummy is a binary variable equal to 1 if the bank is privately held, 0 otherwise. Managerial Ownership is the total cash flow rights of all directors in the board. Bank Type is a binary variable equal to 1 if the bank is a commercial bank, 0 otherwise. Capital Stringency Index measures the regulatory approach to assessing the degree of capital at risk in a bank. This Index is based on the following questions: 1) Is the minimum capital asset ratio requirement risk weighted in line with the Basel guidelines? 2) Does the minimum ratio vary as a function of market risk? 3) Are market values of loan losses not realized in accounting books deducted from capital? 4) Are unrealized losses in securities portfolios deducted? 5) Are unrealized foreign exchange losses deducted? 6) What fraction of revaluation gains is allowed as part of capital? 7) Are the sources of funds to be used as capital verified by the regulatory or supervisory authorities? 8) Can the initial disbursement or subsequent injections of capital be made with assets other than cash or government securities? 9) Can initial disbursement of capital be made with borrowed funds? Restrict Index measures the regulatory barriers for banks to undertake non-lending activities. It measures the extent to which banks are allowed by the regulator to engage in securities market activities (e.g., underwriting, brokering, dealing, and all aspects of the mutual fund industry), insurance activities (e.g., insurance underwriting and selling), real estate activities (e.g., real estate investment, development, and management), and the ownership of non-financial firms. Both Capital Stringency Index and Restrict Index are from Barth et al. (2006). Creditor Rights Index is from La Porta et al. (1998). Depth of Credit Information measures the availability of credit information from either a public registry or a private bureau to facilitate lending decisions. It ranges from 0 to 6 , with higher values indicating more credit information available. It is from Djankov et al. (2007). Financial Statement 
Transparency measures the transparency of bank financial statement practices. Higher values indicate more transparency. It is from Barth et al. (2006).All regressions include country and year fixed effects. Standard errors are correct for heteroskedasticity. The economic impact of each portfolio diversification proxy is reported below the corresponding p-value in bold. The economic impact is calculated as the percentage change of the average bank risk-taking in response to a standard deviation increase of the portfolio diversification variable. In the Survival model the economic impact is calculated using the marginal effect of the portfolio diversification variable. P-values are reported in brackets. $* * *$, and *** report the statistical significance at the $10 \%, 5 \%$, and $1 \%$ levels, respectively. 
Table VIII. Capital allocation results

\begin{tabular}{lcc}
\hline \hline & Ln No. of Firms & $(1-H I)$ \\
\hline Value Added Growth & $0.2611^{* *}$ & $0.2981^{* *}$ \\
& {$[0.0385]$} & {$[0.0126]$} \\
Portfolio Diversification & $-0.0102 * *$ & -0.0419 \\
& {$[0.0438]$} & {$[0.1477]$} \\
Value Added Growth*Portfolio Diversification & $0.0584^{* *}$ & $0.3408^{* *}$ \\
& {$[0.0203]$} & {$[0.0264]$} \\
& $23.73 \%$ & $24.86 \%$ \\
Intercept & & \\
& $0.1780^{* * *}$ & $0.1663 * * *$ \\
Region fixed effects & {$[0.0000]$} & {$[0.0000]$} \\
Year fixed effects & Yes & Yes \\
R-squared & Yes & Yes \\
No. of observations & 0.654 & 0.654 \\
\hline \hline
\end{tabular}

This table reports panel data results at regional level for the capital allocation model. We aggregate both firm- and bank-level data at regional level each year to construct measures of regional capital investment, value added growth and portfolio diversification. The dependent variable (Capital Investment) is $\frac{\Delta \text { Gross } P P E_{r, t}}{\text { Total Fixed } \text { Assets }_{r, t-1}}$, representing the capital expenditure in region $r$ at year $t$, relative to the capital stock; $\Delta$ Gross PPE $_{\mathrm{r}, \mathrm{t}}$ is the annual change in net Total Fixed Assets, with depreciation added back; Total Fixed Assets is the sum of tangible fixed assets, intangible fixed assets, and other fixed assets (all net of accumulated depreciation). Value Added Growth is $\ln \left(\frac{\mathrm{v}_{\mathrm{r}, \mathrm{t}}}{\mathrm{v}_{\mathrm{r}, \mathrm{t}-1}}\right)$ in region $r$ at year $t$ computed as the natural $\log$ of the change in value added between year $t$ and year $t-1$; value added in constant US dollars (year 2000 prices) is defined as earnings before interest and taxes plus the cost of employees. Ln. No of Firm is the average of (Ln. No of Firms) calculated across all banks in each region $r$ each year. (1-HI) is the average of (1-HI) calculated across all banks in each region $r$ each year. All regressions include region and year fixed effects. Standard errors are correct for heteroskedasticity and clustered at region level. The economic impact of Portfolio Diversification proxies reported in bold below the corresponding p-value of the interaction term represents the percentage change of the average capital investment in regions where banks are controlled by shareholders with average portfolio diversification in response to a standard deviation increase in value added growth. P-values are reported in brackets. $*, * *$, and $* * *$ report the statistical significance at the $10 \%$, $5 \%$, and $1 \%$ levels, respectively. 
Table IX. Capital allocation results: robustness tests

\begin{tabular}{|c|c|c|c|c|c|c|c|c|c|c|}
\hline & \multicolumn{2}{|c|}{ Internal Cash Flow } & \multicolumn{2}{|c|}{ Local Finance } & \multicolumn{2}{|c|}{ Bank Competition } & \multicolumn{2}{|c|}{ Shareholders Type } & \multicolumn{2}{|c|}{ Financial Development } \\
\hline & $\begin{array}{l}\text { Ln No. of } \\
\quad \text { Firms }\end{array}$ & $(1-H I)$ & $\begin{array}{l}\text { Ln No. of } \\
\quad \text { Firms }\end{array}$ & $(1-H I)$ & $\begin{array}{l}\text { Ln No. of } \\
\quad \text { Firms }\end{array}$ & $(1-H I)$ & $\begin{array}{l}\text { Ln No. of } \\
\quad \text { Firms }\end{array}$ & $(1-H I)$ & $\begin{array}{l}\text { Ln No. of } \\
\quad \text { Firms }\end{array}$ & $(1-H I)$ \\
\hline \multirow[t]{2}{*}{ Value Added Growth } & $0.2122 *$ & $0.2420 * *$ & $0.1819 *$ & $0.2026^{* *}$ & $0.2125^{*}$ & $0.2424 * *$ & $0.2126^{*}$ & $0.2425 * *$ & $0.2131^{*}$ & $0.2402 * *$ \\
\hline & {$[0.0530]$} & {$[0.0233]$} & {$[0.0817]$} & {$[0.0471]$} & {$[0.0521]$} & {$[0.0226]$} & {$[0.0520]$} & {$[0.0225]$} & {$[0.0505]$} & {$[0.0232]$} \\
\hline \multirow[t]{2}{*}{ Portfolio Diversification } & -0.0074 & -0.0327 & -0.0036 & -0.013 & -0.006 & -0.0298 & -0.006 & -0.0295 & -0.0056 & -0.0282 \\
\hline & {$[0.1474]$} & {$[0.2570]$} & {$[0.4795]$} & {$[0.6376]$} & {$[0.2402]$} & {$[0.3054]$} & {$[0.2395]$} & {$[0.3105]$} & {$[0.2894]$} & {$[0.3316]$} \\
\hline \multirow[t]{3}{*}{ Value Added Growth*Portfolio Diversification } & $0.0521 * *$ & $0.3149 * *$ & $0.0478 * *$ & $0.3009^{* *}$ & $0.0520 * *$ & $0.3158 * *$ & $0.0520 * *$ & $0.3157 * *$ & $0.0505^{* *}$ & $0.3122 * *$ \\
\hline & {$[0.0321]$} & {$[0.0355]$} & {$[0.0468]$} & {$[0.0233]$} & {$[0.0333]$} & {$[0.0356]$} & {$[0.0334]$} & {$[0.0356]$} & {$[0.0380]$} & {$[0.0358]$} \\
\hline & $19.74 \%$ & $20.66 \%$ & $18.19 \%$ & $20.26 \%$ & $19.75 \%$ & $20.70 \%$ & $19.75 \%$ & $20.70 \%$ & $19.64 \%$ & $20.50 \%$ \\
\hline \multirow[t]{2}{*}{ Cash Flow } & $0.1206^{* * *}$ & $0.1212 * * *$ & $0.1206^{* * *}$ & $0.1207 * * *$ & $0.1203 * * *$ & $0.1206^{* * *}$ & $0.1203 * * *$ & $0.1207 * * *$ & $0.1181 * * *$ & $0.1183 * * *$ \\
\hline & {$[0.0000]$} & {$[0.0000]$} & {$[0.0000]$} & {$[0.0000]$} & {$[0.0000]$} & {$[0.0000]$} & {$[0.0000]$} & {$[0.0000]$} & {$[0.0000]$} & {$[0.0000]$} \\
\hline \multirow[t]{2}{*}{ Bank Competition } & & & & & -0.0132 & -0.0137 & -0.0132 & -0.0137 & -0.0133 & -0.0136 \\
\hline & & & & & {$[0.3752]$} & {$[0.3495]$} & {$[0.3759]$} & {$[0.3501]$} & {$[0.3821]$} & {$[0.3603]$} \\
\hline \multirow[t]{2}{*}{ Fraction of Family-Owned Banks } & & & & & & & 0.0019 & 0.0023 & 0.0036 & 0.004 \\
\hline & & & & & & & [0.9377] & {$[0.9273]$} & {$[0.8843]$} & {$[0.8712]$} \\
\hline \multirow[t]{2}{*}{ Financial Development Index } & & & & & & & & & $0.0225^{*}$ & $0.0234 *$ \\
\hline & & & & & & & & & {$[0.0798]$} & {$[0.0663]$} \\
\hline \multirow[t]{2}{*}{ Fraction of listed banks } & & & & & & & & & -0.0097 & -0.0088 \\
\hline & & & & & & & & & {$[0.7327]$} & {$[0.7603]$} \\
\hline \multirow[t]{2}{*}{ Intercept } & $0.0778 * *$ & $0.0733 * *$ & 0.0164 & $0.3267 * * *$ & $0.0748^{* *}$ & $0.0724 * *$ & $0.1145^{* * *}$ & $0.1065^{* * *}$ & $0.0806^{* * *}$ & $0.0718^{* *}$ \\
\hline & {$[0.0190]$} & {$[0.0360]$} & {$[0.6451]$} & {$[0.0000]$} & {$[0.0235]$} & {$[0.0378]$} & {$[0.0000]$} & {$[0.0000]$} & {$[0.0098]$} & {$[0.0168]$} \\
\hline Region fixed effects & Yes & Yes & Yes & Yes & Yes & Yes & Yes & Yes & Yes & Yes \\
\hline Year fixed effects & Yes & Yes & Yes & Yes & Yes & Yes & Yes & Yes & Yes & Yes \\
\hline R-squared & 0.654 & 0.654 & 0.697 & 0.698 & 0.684 & 0.684 & 0.684 & 0.684 & 0.685 & 0.685 \\
\hline No. of observations & 1,038 & 1,038 & 932 & 932 & 1,038 & 1,038 & 1,038 & 1,038 & 1,038 & 1,038 \\
\hline
\end{tabular}


This table reports panel data results at regional level for the capital allocation model. We aggregate both firm- and bank-level data at regional level each year to construct measures of regional capital investment, value added growth and portfolio diversification. The dependent variable (Capital Investment) is

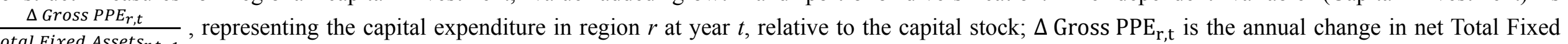
Assets, with depreciation added back; Total Fixed Assets is the sum of tangible fixed assets, intangible fixed assets, and other fixed assets (all net of accumulated depreciation). Value Added Growth is $\ln \left(\frac{\mathrm{V}_{\mathrm{r}, \mathrm{t}}}{\mathrm{V}_{\mathrm{r}, \mathrm{t}-1}}\right)$ in region $r$ at year $t$ computed as the natural $\log$ of the change in value added between year $t$ and year $t-1$; value added in constant US dollars (year 2000 prices) is defined as earnings before interest and taxes plus the cost of employees. Ln. No of Firm is the average of (Ln. No of Firms) calculated across all banks in each region $r$ each year. (1-HI) is the average of (1-HI) calculated across all banks in each region $r$ each year. Cash Flow is equal to $\frac{\text { Cash Flow }_{r, t}}{\text { Total Fixed Assets } r, t-1}$, the ratio of cash flow (as net income plus depreciation) to lagged total fixed assets in region $r$ at year $t$. Bank Competition is equal to the natural log of the number of banks in each region each year. Fraction of Family-Owned Banks is the fraction of banks with an individual (family) as ultimate largest shareholder over the total number of banks in each region each year. The Financial Development Index is calculated at country level as the sum of the Stock Market Development Index and the Financial Intermediary Index, similar to Demirgüç-Kunt and Levine (1996) and Love (2003). Fraction of listed banks is calculated as the number of publicly listed banks divided by the total number of banks in each region $r$ each year. All regressions include region and year fixed effects. Standard errors are correct for heteroskedasticity and clustered at region level. The economic impact of Portfolio Diversification proxies reported in bold below the corresponding $\mathrm{p}$-value of the interaction term represents the percentage change of the average capital investment in regions where banks are controlled by shareholders with average portfolio diversification in response to a standard deviation increase in value added growth. P-values are reported in brackets. *, **, and *** report the statistical significance at the $10 \%, 5 \%$, and $1 \%$ levels, respectively. 